\title{
Engineered In Vitro Models of Tumor Dormancy and Reactivation
}

\author{
Shantanu Pradhan ${ }^{1}$, John L. Sperduto ${ }^{1}$ (D) Cindy J. Farino ${ }^{1}$ and John H. Slater ${ }^{1,2,3^{*}}$
}

\begin{abstract}
Metastatic recurrence is a major hurdle to overcome for successful control of cancer-associated death. Residual tumor cells in the primary site, or disseminated tumor cells in secondary sites, can lie in a dormant state for long time periods, years to decades, before being reactivated into a proliferative growth state. The microenvironmental signals and biological mechanisms that mediate the fate of disseminated cancer cells with respect to cell death, single cell dormancy, tumor mass dormancy and metastatic growth, as well as the factors that induce reactivation, are discussed in this review. Emphasis is placed on engineered, in vitro, biomaterial-based approaches to model tumor dormancy and subsequent reactivation, with a focus on the roles of extracellular matrix, secondary cell types, biochemical signaling and drug treatment. A brief perspective of molecular targets and treatment approaches for dormant tumors is also presented. Advances in tissue-engineered platforms to induce, model, and monitor tumor dormancy and reactivation may provide much needed insight into the regulation of these processes and serve as drug discovery and testing platforms.
\end{abstract}

Keywords: Extracellular matrix, Single cell dormancy, Angiogenic dormancy, Quiescence, Metastasis, Relapse, Hypoxia, Drug Testing, Tissue Engineering, Microphysiological Systems

\section{Introduction}

Metastasis is responsible for the vast majority of cancer-related deaths worldwide, with one study estimating a dismal 5 -year survival rate of only $26 \%$ for metastatic breast cancer patients [1-5]. Even though advances in early detection, diagnosis, and treatment of cancer have significantly improved patient outcome and survival, treatment of metastatic disease is still challenging, with only palliative options available in many cases. A major roadblock in the prevention and treatment of metastasis stems from a lack of understanding of the molecular mechanisms driving metastatic recurrence. This in part stems from the high degree of inter-tumoral and intra-tumoral heterogeneity, making it difficult to predict treatment outcomes. Cancer recurrence postsurgery, and after termination of therapy, has been a commonly observed problem across many cancer types $[1,6-10]$. Patients diagnosed at an early stage with small

\footnotetext{
* Correspondence: jhslater@udel.edu

${ }^{1}$ Department of Biomedical Engineering, University of Delaware, 150

Academy Street, 161 Colburn Lab, Newark, DE 19716, USA

²Delaware Biotechnology Institute, 15 Innovation Way, Newark, DE 19711,

USA

Full list of author information is available at the end of the article
}

tumors, and no lymphatic presence, have a $25-30 \%$ chance of recurrence after 10-15 years [11]. Analysis of long-term survival outcomes of patients suggests that the probability of metastatic recurrence and death follows two distinct peaks: one at 1-2 years and another at 5 years post-surgery. Early detection and adjuvant chemotherapy provide some prevention for early relapse but neither approach is effective at preventing relapse after 5 years [11-13].

Over the past few decades, researchers have postulated and demonstrated the presence of residual and disseminated tumor cells in patients that undergo a period of latency or dormancy [6, 14-17]. This latency period can range from a few months to as long as decades, depending on the cancer subtype, molecular characteristics and receptor status, patient lifestyle, systemic inflammation and a host of other factors [9, 16-20]. However, upon being stimulated by specific microenvironmental factors, these dormant cells can become activated, form micrometastases, and eventually macrometastases, often with increased chemoresistance, leading to poor patient outcome and reduced survival [20-22]. Hence, preemptively targeting dormant tumor cells offers a potential window

(c) The Author(s). 2018 Open Access This article is distributed under the terms of the Creative Commons Attribution 4.0 International License (http://creativecommons.org/licenses/by/4.0/), which permits unrestricted use, distribution, and 
of opportunity for prevention of metastatic relapse in patients.

This review provides an overview of engineered, in vitro, models that have been developed to investigate the roles that microenvironmental factors play in inducing and regulating tumor dormancy. Microenvironmental factors that induce, regulate, and maintain tumor dormancy are classified into four subgroups: 1) extracellular matrix (ECM), 2) signaling from secondary cell types, 3) biochemical factors and 4) drug treatment, and their distinct roles are summarily described. Engineered models developed to investigate escape from dormancy through reactivation and for identifying and testing potential drug candidates are also reviewed. It is hoped that the clinical challenges related to tumor dormancy gain wider attention in the biomaterials and tissue engineering communities, to focus efforts toward development of advanced recapitulative models of the dormant tumor niche, and for identifying dormancy-associated targets for drug development.

\section{Tumor dormancy}

The temporal progression of metastasis starting with cell escape from the primary tumor and resulting in secondary tumors in foreign tissue is termed the 'metastatic cascade'. Cells originating from a primary tumor can invade the surrounding tissue, intravasate into nearby blood vessels, travel through systemic vasculature as circulating tumor cells (CTCs), extravasate into secondary tissues (e.g. brain, liver, lung, bone marrow), and form metastases [23, 24]. The hematogenous metastatic process is extremely inefficient as only a small percentage of disseminated tumor cells form metastases [2528]. Clinical studies of metastatic recurrence and mathematical modeling of tumor regrowth kinetics indicate that disseminated tumor cells may lie dormant for extended periods of time prior to being stimulated into an active growth state [17, 19, 29-33]. Additionally, tumor cells may disseminate early from a primary tumor (which is still clinically undetectable) and appear as metastatic tumors in secondary organs prior to detection of the primary tumor, leading to classification as tumors of unknown origin [34, 35]. These occult indolent tumors may lie dormant throughout the lifetime of the patient, primarily due to immune regulation [21, 36-38]. Interestingly, the primary tumor is also hypothesized to create 'stress microenvironments' for disseminated tumor cells by stimulating systemic immunoregulatory action and subsequently preventing dormant tumor cells from being activated [35, 39-41].

Various scenarios concerning the fate of extravasated tumor cells have been proposed and validated using in vivo models $[16,42]$. These scenarios describe the existence and persistence of dormant tumor cells in secondary niches along with a multitude of factors (signaling from secondary cell types, ECM properties, and biochemical factors), some of which induce cell quiescence and cancer latency. Multiple theories concerning the prevalence of one scenario over others have been proposed, but in reality, the co-existence of these scenarios in parallel is quite likely; although not yet definitively demonstrated in clinical studies [30, 43]. These scenarios are presented as potential fates which disseminated cells may undergo in secondary niches either through tumor-intrinsic or tumor-extrinsic pathways (Fig. 1).

\section{Cell death}

A majority of disseminated cells die either in the systemic cardiovasculature or after extravasation into secondary tissue. Death of CTCs during circulation is chiefly mediated by vascular stress and immunomodulatory mechanisms of macrophages, leukocytes, and platelets, resulting in a short half-life of only 2-3 hours [17, 19, 44]. CTCs that do survive, and are able to colonize secondary tissue, face additional microenvironmental stress and immunomodulatory suppression in the complex milieu, which is generally very different from the primary tumor niche [17, 25, 45]. Hence, death via apoptosis and anoikis is common in a majority of disseminated cells [25, 46]. Interestingly, some ovarian cancer cells have been observed to use autophagy-related mechanisms to survive as dormant cells in the in vivo tumor microenvironment [47].

\section{Cellular dormancy}

A majority of surviving cells in the dormant niche are believed to survive as single cells with $\mathrm{G}_{0}$ cell cycle arrest, altered metabolic profiles and induction of anti-apoptotic cell survival mechanisms [25, 48-50]. The presence of persistent single tumor cells in various secondary niches (e.g. bone marrow, brain perivascular niche) has been experimentally observed in in vivo models and in human subjects with no clinically detectable disease $[19,51,52]$. The intrinsic and extrinsic factors that support this population of dormant cells for extended time periods have only been recently explored, although much progress is needed in determining and identifying the potential of these single cells toward activation and tumor growth [11, 21, 34, 53-55]. Evolutionary theories posit that complete eradication of these dormant cells may be too far-fetched; however, efforts to induce and maintain the cells in a dormant state for long time periods are currently being explored [34].

\section{Tumor mass dormancy}

In addition to dormant single cells, small cell clusters maintaining a delicate balance between proliferation and 


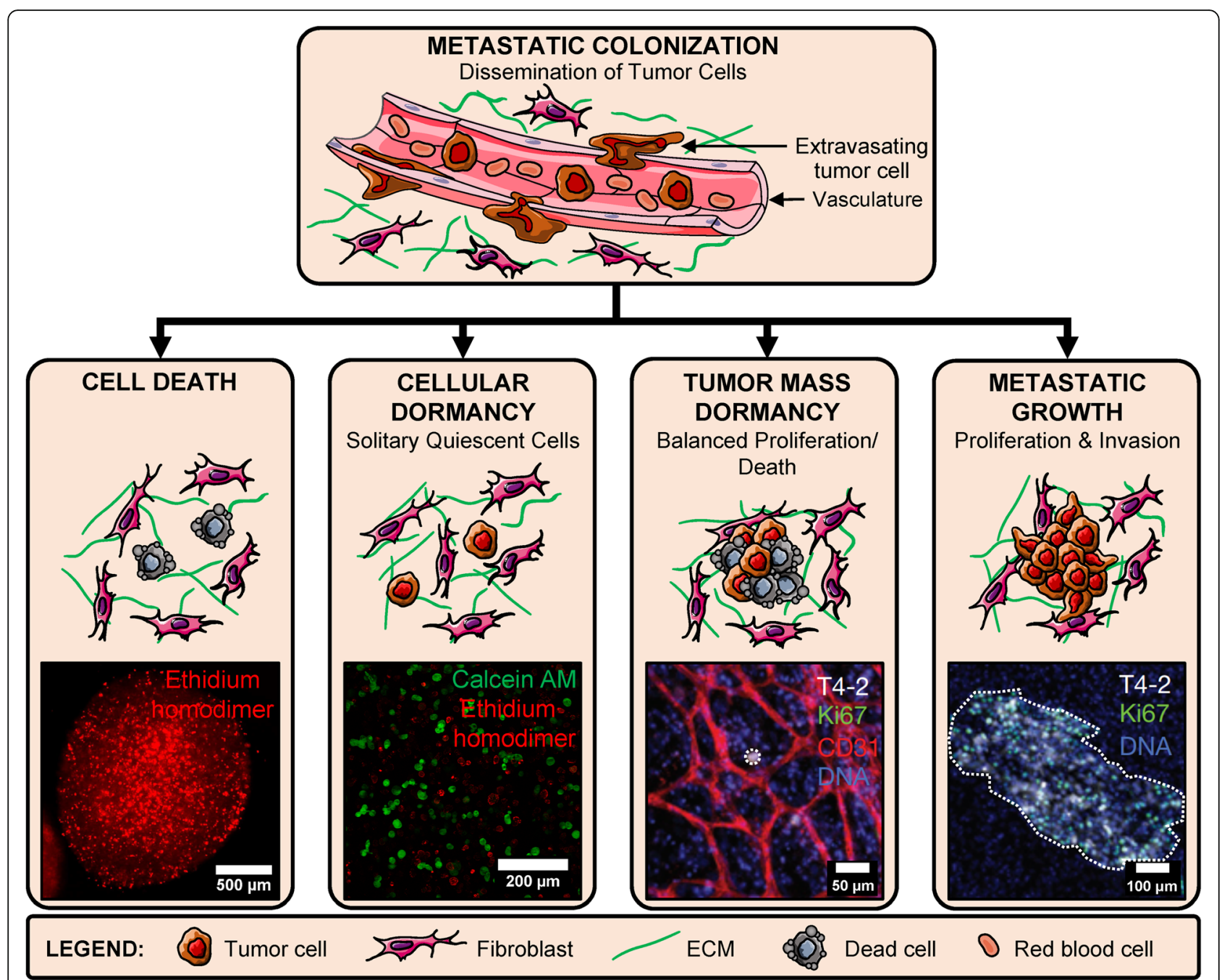

Fig. 1 Fate of disseminated tumor cells. Circulating tumor cells extravasate from vasculature at secondary sites and undergo one of four fates in the secondary niche: cell death (primarily via apoptosis), cellular dormancy (remain as single quiescent cells), tumor mass dormancy (small clusters with balanced proliferation and apoptosis) and metastatic growth (high proliferation and invasion). Cell Death: representative image of MCF7 cancer cells within hydrogel millibeads fluorescently labeled with ethidium homodimer (red) (Adapted from [90]) Copyright 2014, ACS. Cellular Dormancy: representative image of MDA-MB-231 breast cancer cells within hydrogels fluorescently labeled with calcein AM (green)/ethidium homodimer (red) (unpublished). Tumor Mass Dormancy: HMT-3522-T4-2 breast cancer cells cultured with lung stromal cells and endothelial cells form a small, non-proliferative colony (dotted circle) (Adapted from [42]). Metastatic Growth: HMT-3522-T4-2 cells cultured with lung stromal cells develop into invasive, proliferative clusters representative of metastatic outgrowth (dotted region) (Adapted from [42]). Copyright 2013, Springer Nature

apoptosis may occur in a manner that prevents tumor growth. These small clusters are often discounted as dysplastic local tissue [56]. Small cell clusters in balanced dormancy contain low proliferation and a mix of pro-angiogenic and anti-angiogenic stromal and cellular cues that balance each other to maintain tumoral homeostasis [11, 34, 36]. This state is also referred to as balanced population dormancy and can be further sub-divided into: 1) immune-suppressed dormancy (mediated by persistent cytotoxic activity of immune cells to restrict tumor growth) and 2) pre-angiogenic dormancy (caused by a lack of angiogenic signaling and deficiency of nutrients, characterized by avascular and whitish masses) $[11,49,50,57,58]$. In some cases, these clusters may become larger than 1-2 $\mathrm{mm}$ without vascularization and form distinct central necrotic cores. These small tumor masses have been demonstrated to harbor a pool of stem cells which undergo asymmetric cell division to maintain a balance of proliferative and apoptotic cells $[59,60]$. A number of studies demonstrating the presence and temporal evolution of avascular dormant tumors have been conducted to investigate the role of microenvironmental factors regulating this dormancy state [61-64]. However, competing theories suggest that population dormancy is much rarer than single cell dormancy and may possibly be a temporal step of 
single dormant tumor cells heading toward metastatic outgrowth $[29,65]$.

\section{Metastatic outgrowth}

Dormant single cells or avascular cell clusters can be triggered toward aggressive and invasive growth upon stimulation by various factors including angiogenic sprouting, inflammatory cytokines, aberrations in stromal cues, and others $[21,22,42,66]$. This change in state often leads to metastatic colonization, inhibition of secondary organ function, and is the prime cause of metastatic relapse and death among patients. Metastatic relapse has been studied extensively in animal models and current efforts are directed toward prevention or delay of this phenomenon to increase patient survivability $[9,62,63,67]$.

The molecular and genetic mechanisms underlying cellular dormancy, tumor mass dormancy, and tumor cell survival in dormancy-inducing niches, as well as reactivation, have been extensively reviewed previously $[18,25$, $26,45,49,68-76]$. Integrin engagement of dormant tumor cells with the surrounding ECM has been implicated in maintaining cellular quiescence $[20,77,78]$. Biological observations of tumor dormancy have mostly been restricted to animal models, due to a lack of well-defined in vitro models [54, 57, 79, 80]. While animal models provide a high degree of physiological context, they entail several limitations with respect to investigating dormancy [11, 43, 81]. Longitudinal detection, observation and fate-tracking of single tumor cells or small cell clusters simultaneously within multiple organs of a complex organism is severely restricted by current imaging limitations, although some advances are being made in this aspect [82-84]. The choice of cell lines for investigating dormancy in vivo is not appropriately classified yet; aggressive cell lines in two-dimensional (2D) culture may form overt macrometastases in animals within a shorter time frame than what may be required to study long-term dormancy, while cell lines ideal for studying dormancy may be misclassified as non-malignant or non-tumorigenic [11]. Additionally, inducing spontaneous dormancy in animals is difficult due to the stochastic nature of metastasis and tumor growth [81]. Most of the knowledge concerning in vivo dormancy has been obtained from histological analysis, using chick chorioallantoic membrane (CAM) models or models using superficial anatomic sites where the cell fate can be tracked which is often difficult for internal organs [11, 36, $64,85]$. Engineered, in vitro models may provide a means to overcome some of the limitations associated with animal studies while also providing more control over the parameters thought, or known, to induce dormancy. Recent efforts to implement engineered models to induce, model, and investigate the roles of microenvironmental factors in these processes are discussed in the following sections.

\section{In vitro approaches to model tumor dormancy}

Current efforts in tissue engineering to generate cancer models are often implemented to investigate the metastatic cascade, recapitulate the aberrant tumor microenvironment, for biophysical and biochemical regulation of cancer cell behavior, and for drug development. However, in vitro models to investigate dormancy are far fewer in number [86]. One of the reasons for the paucity in dormancy models is the lack of a definitive roadmap for analysis, classification and characterization of dormant cell behavior spanning multiple cancer types, as well as establishment of well-defined dormancy metrics. However, with advances in dormancy biology and in biomaterial, biofabrication and microfluidic technologies, novel in vitro dormancy models are being developed (Table 1). These models are expected to provide deeper insight into the molecular mechanisms regulating dormancy while providing facile, higher-throughput and well-controlled microenvironments for drug discovery.

We classified existing engineered tumor dormancy models based on the mode of dormancy induction: 1) ECM-induced, 2) cell signaling-induced, 3) biochemicalinduced and 4) drug-induced (Fig. 2). Efforts to create engineered models to investigate the influence of these various dormancy-inducing sources are discussed in detail below.

\section{ECM-induced dormancy}

The most common method of ECM-mediated dormancy induction is via physical confinement of cancer cells within dense matrices that restrict proliferation, spreading, and invasion while increasing apoptosis, thereby regulating overall tumor cell quiescence and population balance [87-89]. Cancer cells, owing to their inherent robustness, are able to survive in stressful microenvironments in a dormant state and this phenomenon is exploited in vitro for modeling of dormant tumor microenvironments $[65,88,90]$. Mechanical and physical confinement of single tumor cells or tumor spheroids has been achieved using several biomaterials including collagen/gelatin, Matrigel, agarose, poly(ethylene glycol) (PEG)-based hydrogels, poly( $\varepsilon$-caprolactone) (PCL) and interpenetrating networks (IPNs) of different materials [87-96] (Fig. 3a-c). Biomaterial-based entrapment of tumor cells is dependent on modulation of crosslinking density, pore size, matrix degradability, solid stress, matrix stiffness, or a combination of these factors. These approaches can be more effective at inducing dormancy, compared to serum starvation to induce quiescence [87, 88]. A summary of biomaterial/ECM-based approaches for inducing dormancy and their associated mechanisms is provided in Table 2 .

Collagen has been modified in several ways to modulate the behavior of encapsulated cancer cells. These 
Table 1 Summary of in vitro dormancy models classified by cancer/cell type and mode of dormancy induction with associated metrics used to determine dormancy status

\begin{tabular}{|c|c|c|}
\hline Cancer/Cell Type & Mode of Dormancy Induction & Metrics Analyzed \\
\hline $\begin{array}{l}\text { Breast Cancer } \\
\text { - MDA-MB-231 [43, 59, 82, 88, 91, 93, } \\
\text { 96, 98, 106, 116, 118-120,127, 128, } \\
\text { 132, 135-137, 156, 179] } \\
\text { - MDA-MB-231BRMS1 [139] } \\
\text { - MCF-7 [43, 44, 59, 82, 89,93,98, } \\
\text { 118, 128, 132, 134-137, 139, 176] } \\
\text { - T47D }[95,121,133,135,138,177,179,181] \\
\text { - MDA-MB-435 [58, 176] } \\
\text { - MDA-MB-468 [133] } \\
\text { - MDA-MB-453 [58] } \\
\text { - ZR-75-1 [58] } \\
\text { - SUM149 [58] } \\
\text { - SUM159 [58, 148] } \\
\text { - BT474 [58] } \\
\text { - D2.0R [162, 163, 196] } \\
\text { - 4T1 [176] }\end{array}$ & $\begin{array}{l}\text { ECM-Induced } \\
\text { - Matrix Stiffness/Physical Confinement [87-90, 92] } \\
\text { - Matrix Composition/ Architecture [92, 97, 105] } \\
\text { - Integrin Engagement [135, 137, 138, 162, 163, 196] } \\
\text { Cell Signaling-Induced } \\
\text { - Endothelial Cells }[42,58,81,105,119] \\
\text { - Hepatocytes/NPCs }[81,105,119] \\
\text { - MSCs [42, 58, 117, 122, 179] } \\
\text { - Fibroblasts [42, 58, 120] } \\
\text { - Osteoblasts [58, 139] } \\
\text { - Exosomes/EVs [121, 122] } \\
\text { Biochemical-Induced } \\
\text { - Hypoxia [128, 129, 133] } \\
\text { - FGF-2 [135-138, 140, 181] } \\
\text { - Thrombospondin [42] } \\
\text { Drug-Induced } \\
\text { - Doxorubicin [81, 148] } \\
\text { - Docetaxel [148] } \\
\text { - Carboplatin [95] }\end{array}$ & $\begin{array}{l}\text { - Proliferation }[42,58,81,87,88,95,105, \\
117,119,129,148,163,172] \\
\text { - Cell Cycle Analysis }[95,117,120,121,179] \\
\text { - Metabolic Activity }[88,89,95,119,133] \\
\text { - Viability }[87-90,95,120,181] \\
\text { - Morphology }[43,91,93,98,119,127,138, \\
\text { 139, 162, 177, 196] } \\
\text { - Gene/Protein Expression }[42,81,95,105,117, \\
\text { 119, 120, 133, 135-138, 140,162,172, 196] } \\
\text { - Invasion/Motility }[42,87,95,97] \\
\text { - Chemoresistance }[89,128,172,177] \\
\text { - Stem Cell Expression }[95,117,122]\end{array}$ \\
\hline $\begin{array}{l}\text { Prostate Cancer } \\
\text { - PC-3 }[117,118,120,176] \\
\text { - DU145 }[148,176,177] \\
\text { - C4-2B }[128] \\
\text { - LnCAP }[88]\end{array}$ & $\begin{array}{l}\text { ECM-Induced } \\
\text { - Matrix Stiffness/Physical Confinement [88] } \\
\text { Cell Signaling-Induced } \\
\text { - Prostate Stromal Cells [120] } \\
\text { - Endothelial Cells [118] } \\
\text { - MSCs [117, 118] } \\
\text { Biochemical-Induced } \\
\text { - Hypoxia [128] } \\
\text { Drug-Induced } \\
\text { - Docetaxel [148] }\end{array}$ & $\begin{array}{l}\text { - Proliferation }[118,148] \\
\text { - Metabolic Activity }[88] \\
\text { - Morphology }[117,118,128] \\
\text { - Chemoresistance }[176,177]\end{array}$ \\
\hline $\begin{array}{l}\text { Lung cancer } \\
\text { - A549 }[94,117,178] \\
\text { - PC-9 [157] } \\
\text { - H1975 [104] }\end{array}$ & $\begin{array}{l}\text { ECM-Induced } \\
\text { - Physical confinement [94] } \\
\text { - Mechanical forces [104] } \\
\text { Cell Signaling-Induced } \\
\text { - MSCs [117] }\end{array}$ & $\begin{array}{l}\text { - Proliferation [104] } \\
\text { - Cell Cycle Analysis [94] } \\
\text { - Morphology [94, 104, 117] } \\
\text { - Gene/Protein Expression [94, 104, 157, 178] } \\
\text { - Invasion/Motility [94, 104] } \\
\text { - Chemoresistance }[94,104,157,178]\end{array}$ \\
\hline $\begin{array}{l}\text { Colorectal/Colon Cancer } \\
\text { - DLD-1 [177] } \\
\text { - LoVo }[147] \\
\text { - HCT-116 [89, 128, 147] } \\
\text { - Primary colon cancer cells }[147,177]\end{array}$ & $\begin{array}{l}\text { ECM-Induced } \\
\text { - Matrix Stiffness/Physical Confinement [89] } \\
\text { Biochemical-Induced } \\
\text { - Hypoxia [128] } \\
\text { - EGF [147] } \\
\text { Drug-Induced } \\
\text { - 5-FU [147] }\end{array}$ & $\begin{array}{l}\text { - Proliferation [147] } \\
\text { - Metabolic Activity }[89,128] \\
\text { - Viability }[89,177] \\
\text { - Morphology }[89,128] \\
\text { - Chemoresistance }[89,128,177]\end{array}$ \\
\hline $\begin{array}{l}\text { Pancreatic Cancer } \\
\text { - PANC-1 [117] } \\
\text { - Capan-1 [176] } \\
\text { - CFPAC }[89]\end{array}$ & $\begin{array}{l}\text { ECM-Induced } \\
\text { - Matrix Stiffness/Physical Confinement [89] } \\
\text { Cell Signaling-Induced } \\
\text { - MSCs [117] }\end{array}$ & $\begin{array}{l}\text { - Proliferation [89] } \\
\text { - Metabolic Activity [89] } \\
\text { - Viability [89] } \\
\text { - Morphology [89, 117] } \\
\text { - Chemoresistance }[89,176]\end{array}$ \\
\hline $\begin{array}{l}\text { Other Cancers } \\
\text { - Bladder Cancer (T24, UMUC-3, J82) } \\
\text { [120, 176] } \\
\text { - Oral Squamous Cell Carcinoma } \\
\text { (SCC-71) [128] } \\
\text { - Osteosarcoma (U2OS, MG63, Saos-2) } \\
\text { [58, 128] } \\
\text { - Gastric Cancer (AGS) [176] } \\
\text { - Glioblastoma (U251) [176] } \\
\text { - Ovarian Cancer (OVCAR-5) [88] }\end{array}$ & $\begin{array}{l}\text { ECM-Induced } \\
\text { - Matrix Stiffness/Physical Confinement }[88,128] \\
\text { Cell Signaling-Induced } \\
\text { - Endothelial Cells [58] } \\
\text { - MSCs [58] } \\
\text { - Osteoblasts [58] } \\
\text { - Prostate Stromal Cells [120] } \\
\text { - Fibroblasts [120] }\end{array}$ & $\begin{array}{l}\text { - Proliferation [58, 128] } \\
\text { - Cell Cycle Analysis [120] } \\
\text { - Metabolic Activity }[88,128] \\
\text { - Viability }[88,120] \\
\text { - Chemoresistance }[128,176]\end{array}$ \\
\hline
\end{tabular}

Abbreviations: 5-FU 5-Fluorouracil, ECM Extra-Cellular Matrix, EGF Epidermal Growth Factor, EVs Extracellular Vesicles, FGF-2 Fibroblast Growth Factor-2, MSCs Mesenchymal Stem/Stromal Cells, NPCs Non-Parenchymal Cells

include addition of transglutaminase to increase matrix crosslinking density and stiffness, varying concentration and crosslinking $\mathrm{pH}$ to modulate fibril diameter, fibril length, pore size, and elastic modulus, as well as formation of IPNs with PEG to increase matrix stiffness and reduce porosity [87, 89, 97] (Fig. 3b). Interestingly, 


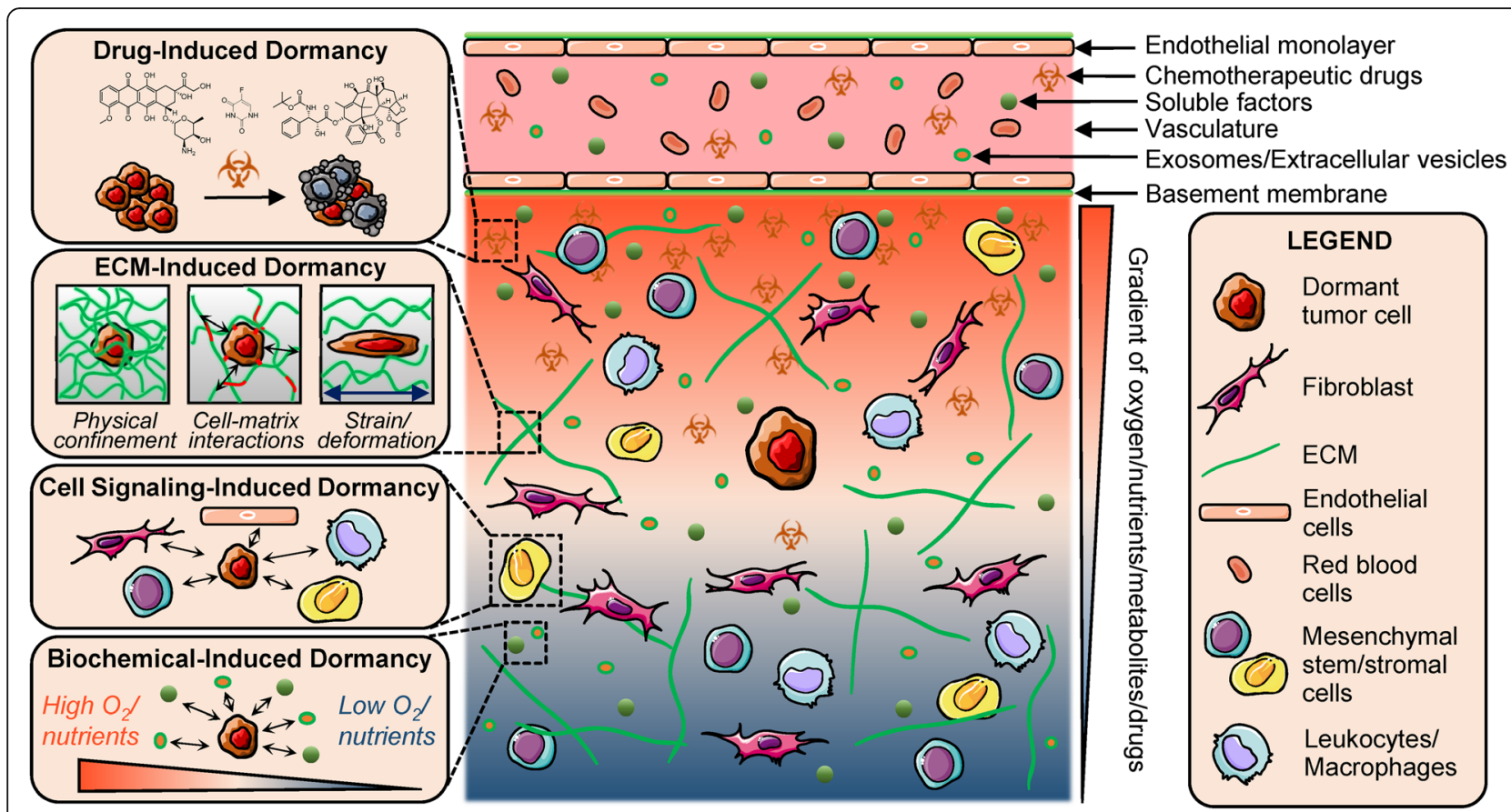

Fig. 2 Modes of dormancy induction. Engineered, in vitro models of tumor dormancy can be classified based on the mode of dormancy induction: drug-induced dormancy (selective elimination and survival of sub-populations under chemotherapeutic treatment), ECM-induced dormancy (biophysical constraints imposed on cancer cells by the surrounding matrix), cell-signaling induced dormancy (paracrine signaling from stromal cells and vasculature) and biochemical-induced dormancy (influence of soluble factors, hypoxia and nutrients)

cancer cells with differing inherent characteristics (epithelial vs. mesenchymal) can display widely differing behavior even under similar matrix conditions. For example, Sapudom et al. showed MCF7 breast cancer cells (epithelial in nature) remained as single, rounded cells within collagen matrices with a larger fibril diameter $(850 \mathrm{~nm})$ and associated pore size of $5.5-11 \mu \mathrm{m}$, while MDA-MB-231 cells (mesenchymal in nature) remained as rounded cells in matrices with a smaller fibril diameter $(550 \mathrm{~nm})$ and pore size of $11 \mu \mathrm{m}$ [97]. These differences highlight the importance of both matrix microarchitecture and the cell type being investigated to attain the desired dormant tumor cell morphology.

Regulation of cell-mediated matrix degradability via modulation of PEG composition and content has also been applied to induce dormancy $[88,90,92,98]$. These microarchitectural changes may also induce changes in diffusion of nutrients, oxygen, and cellular metabolites which could cause changes in cancer cell behavior through secondary and potentially uncontrolled mechanisms [87, 90]. In many engineered matrices, microarchitectural characteristics are coupled with each other, making it challenging to elucidate the role of individual factors toward regulating cancer cell behavior. However, some matrices allow independent control of these parameters which led to the conclusion that solid stress imposed by the matrix, and physical restriction of tumor cells in confined matrices, is a prime driver in maintaining quiescence and dormancy [88, 91, 99]. PEG-based matrices also facilitate investigation of single cell dormancy, provided that the chosen cancer cell lines are robust enough to survive within non-degradable and non-bioactive matrices, albeit for a few days in culture [88, 90].

The principal mechanisms underlying confinement-induced dormancy are attributed to decreased proliferation, increased cell death via apoptosis and limited integrin engagement, thereby making these matrices suitable for studying balanced or tumor mass dormancy. In two related studies by Liu et al., stiffer fibrin gels $(1000 \mathrm{~Pa})$ and softer collagen gels $(100 \mathrm{~Pa})$ restricted tumor growth while softer fibrin gels $(100 \mathrm{~Pa})$ promoted tumorigenicity [100, 101]. Mechanistic investigation revealed that a stiffer environment led to nuclear translocation of $\mathrm{Cdc} 42$, a cytosolic mechanotransducer, promoting transcription of Tet2, epigenetic upregulation of p21 and p27 with simultaneous downregulation of $\beta_{3}$ integrin. Therefore, dual regulation of cell cycle progression and cell-matrix engagement can be attributed to matrix-induced dormancy [101].

The mechanisms underlying cell death due to physical confinement have been investigated in detail and may provide clues in choosing or designing matrices to study 


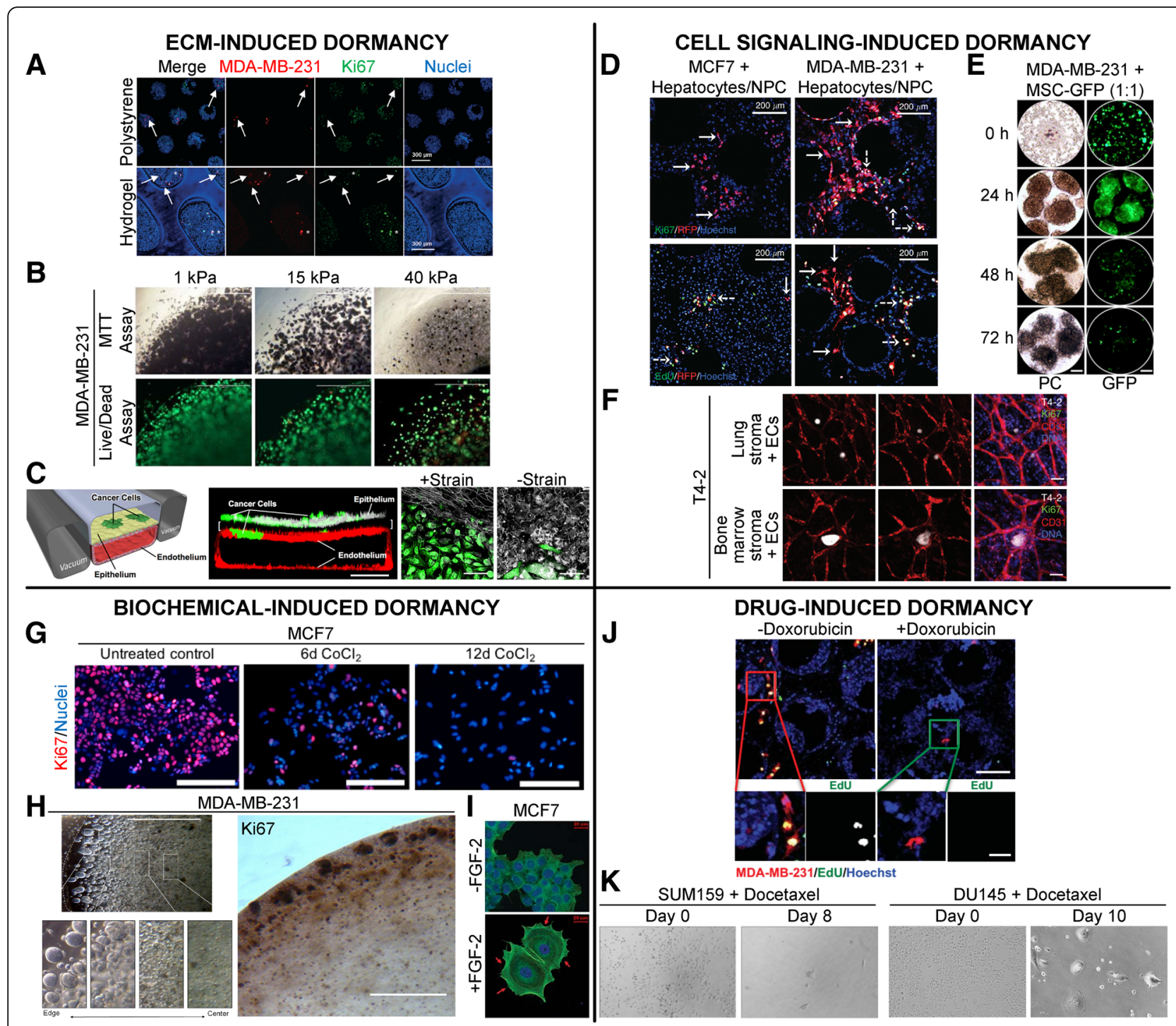

Fig. 3 Engineered, in vitro models for induction of cancer dormancy. Representative examples of in vitro dormancy models classified by induction mode. a MDA-MB-231-RFP cells co-cultured with primary human hepatocytes and non-parenchymal cells (NPCs) within a hepatic microphysiological system either seeded on a polystyrene surface or encapsulated within a PEG-peptide hydrogel matrix and imaged on day 15. Arrows: dormant cells, asterisks: proliferative cells. Scale bar = $300 \mu \mathrm{m}$. (Adapted from [105]). Copyright 2017, RSC. b MDA-MB-231 cells cultured within Col-Tgel hydrogels demonstrate an increased dormancy signature characterized by reduced MTT staining, reduced cell death and lower cell density. Green: calcein AM, red: ethidium homodimer. Scale bar $=1000$ um. (Adapted from [89]). Copyright 2017, Springer Nature. c GFP expressing, non-small-cell lung cancer cells (NSCLC) cultured with alveolar epithelial cells and lung microvascular endothelial cells within a microfabricated lung-on-a-chip device for 2 weeks to investigate the role of physiological breathing motions on the growth/dormancy of cancer cells. Red: VE-cadherin, white: ZO-1 tight junctions, Scale bar $=200 \mu \mathrm{m}$ (center), $50 \mu \mathrm{m}$ (right). (Adapted from [104]). Copyright 2017, Elsevier. d RFP expressing breast cancer cells cultured with hepatocytes and NPCs within a liver microphysiological system for 2 weeks and fluorescently labeled for Ki67 or EdU (green) and nuclei (blue). Scale bar $=200 \mu \mathrm{m}$. Solid white arrows: dormant cells, dashed white arrows: proliferative cells. (Adapted from [119]). Copyright 2014, NPG. e MDA-MB-231 cells cultured with GFP expressing MSCs and imaged under phase contrast (PC) and green fluorescence (GFP) at varying time points are observed to cannibalize MSCs within 3D spheroids and enter dormancy, leading to reduced GFP signal intensity. Scale bar $=100 \mu \mathrm{m}$. (Adapted from [117]). Copyright 2016, NAS. f HMT-3522-T4-2 breast cancer cells cultured with lung/bone marrow stromal cells and endothelial cells remain as dormant clusters through day 17 with low proliferation. Scale bar = $100 \mu \mathrm{m}$. (Adapted from [42]). Copyright 2013, NPG. g MCF7 cells treated with $300 \mu \mathrm{M}$ CoCl 2 undergo hypoxia and enter dormancy with low proliferation. Scale bar $=200 \mu \mathrm{m}$. (Adapted from [129]). Copyright 2018, Springer Nature. h MDA-MB-231 cells within Col-Tgel hydrogels exhibit reduced proliferation and cluster size with increasing distance from the hydrogel edge due to a hypoxia gradient. Scale bar $=100 \mu \mathrm{m}$. (Adapted from [128]). Copyright 2014, PloS. i MCF7 cells seeded on a fibronectin-coated substrate and treated with FGF-2 undergo a dormancy phenotype with cortical actin redistribution around the perimeter of the cytoplasm (red arrows). Scale bar $=20 \mu \mathrm{m}$. (Adapted from [137]). Copyright 2009, Springer. j MDA-MB-231 cells in an engineered liver niche treated with doxorubicin exhibit reduced proliferation compared to the control group. Scale bar = $200 \mu \mathrm{m}$ (top), 50 m (bottom). (Adapted from [81]). Copyright 2013, ASBMB. k Breast and prostate cancer cells treated with docetaxel exhibit residual tumor cells with dormancy signatures. (Adapted from [148]). Copyright 2014, PloS 
Table 2 ECM-based matrices to induce dormancy

\begin{tabular}{lll}
\hline Biomaterial/ECM & Characteristics & Mechanism Inducing Dormancy \\
\hline Collagen/Gelatin [89] & $\begin{array}{l}\text { Naturally occurring animal-derived biopolymer with collagen/gelatin } \\
\text { backbone crosslinked with transglutaminase }\end{array}$ & $\begin{array}{l}\text { Increased stiffness resulting from increased } \\
\text { crosslinking density of gelatin precursor }\end{array}$ \\
Agarose [91, 93] & $\begin{array}{l}\text { Plant-derived biopolymer physically crosslinked at ambient } \\
\text { temperature }\end{array}$ & $\begin{array}{l}\text { Mechanical stress arising from a confining, } \\
\text { non-adhesive matrix }\end{array}$ \\
Matrigel [94] & $\begin{array}{l}\text { Mouse-tumor derived matrix consisting of collagen, laminin, elastin } \\
\text { and growth factors amongst other components }\end{array}$ & Physical confinement in a 3D matrix \\
Fibrin [100, 101] & $\begin{array}{l}\text { Naturally occurring biopolymer in blood obtained via crosslinking of } \\
\text { fibrinogen with thrombin }\end{array}$ & Matrix stiffness \\
PEG [90] & $\begin{array}{l}\text { Synthetic bio-inert polymer that can be chemically and mechanically } \\
\text { tuned }\end{array}$ & Non-degradability and physical confinement \\
Silica-PEG [88] & $\begin{array}{l}\text { Silicate network gel formed via hydrolysis of silicon alkoxide and } \\
\text { condensation reaction to form a porous silica network, with PEG } \\
\text { porogen and silica nanoparticles }\end{array}$ & $\begin{array}{l}\text { Physical confinement in a non-degradable } \\
\text { matrix }\end{array}$ \\
Collagen-PEG IPN [87] & $\begin{array}{l}\text { Double crosslinked network of collagen and PEG with varying PEG } \\
\text { concentrations }\end{array}$ & $\begin{array}{l}\text { Physical confinement in an increasingly } \\
\text { non-degradable matrix }\end{array}$ \\
PEG-protein and PEG-peptide \\
blends [92, 105]
\end{tabular}

Abbreviations: 3D Three-dimensional, ECM Extracellular matrix, IPN Interpenetrating network, PEG Poly(ethylene glycol);

population dormancy. In non-permissive matrices, cells within dense spheroids or near central regions of the hydrogel may be limited in nutrients and oxygen leading to hypoxia and eventual necrosis $[89,90]$. In other cases, apoptosis is the common mode of cell death, which can be induced by a number of factors including restricting $\beta_{1}$-integrin engagement and preventing cell spreading [91, 93, 99]. Mechanical confinement has also been observed to interfere with nuclear division geometry and orientation leading to increased mitotic delay (specifically prometaphase), asymmetric multi-polar cell division, chromosome misalignment, daughter cell aneuploidy and eventual apoptosis [102, 103].

In addition to biomaterial design, advances in microfabrication and on-chip technologies have facilitated the study of liver cancer and lung cancer dormancy which incorporate multiple microphysiological cues including regulation of integrin-engagement, fluid pressure, mechanical aeration and cyclic deformation. These approaches have provided significant insights into potential targets and drug responsiveness [104, 105] (Fig. 3c). Inherent ECM cues present in tropic niches can also induce dormancy in different cancer cell types. The review by Ghajar provides a brief synopsis of some of these cues located in the lung, bone marrow and brain perivascular niches which confer dormancy signatures on cancer cells [106]. Chief among them are osteopontin and laminin, which regulate pro-survival mechanisms and therapeutic resistance in acute lymphoblastic leukemia cells, lung cancer and glioblastoma [107-110]. Overall, intelligent design of biomaterial platforms can facilitate the investigation of factors inducing cellular quiescence and tumor dormancy with a high degree of physiological complexity and direct control over desired matrix properties.

\section{Cell signaling-induced dormancy}

Over the past few years, there has been significant interest in recapitulating the dormant secondary milieu, particularly the bone marrow, by co-culturing bone marrow stromal cells with cancer cells. The primary reason for this approach is that the complex bone marrow microenvironment is believed to contain microniches that induce tumor dormancy for extended periods of time [35, $42,106,111-114]$. These niches confer dormancy on cancer cells via intercellular signaling leading to growth arrest, activation of pro-survival mechanisms and anti-apoptotic mechanisms, and enhanced chemotherapeutic resistance $[106,114,115]$. In a landmark study by Ghajar et al., breast cancer cells were co-cultured in lung-mimetic or bone-marrow mimetic perivascular niches and thrombospondin-1 (TSP1) secreted by stable endothelial networks was observed to maintain tumor cells in a dormant, non-proliferative state, with a possible supportive role of bone morphogenetic protein 4 (BMP4) [42, 116] (Fig. 3f).

The role of various secondary cell types in the bone marrow microenvironment has been modeled in several in vitro studies [42, 58, 104, 117]. However, the context in which these cells (mesenchymal stem/stromal cells (MSCs), endothelial cells (ECs), and cancer cells) are co-cultured often varies, making it difficult to compare and attribute specific contributions of each cell type toward dormancy induction. For example, bone marrow MSCs co-cultured with metastatic MDA-MB-231 breast cancer cells led to the cannibalism of the MSCs by the cancer cells within 72 hours. Bartosh et al. demonstrated that internalization of MSCs induced the cancer cells to enter a dormant phase characterized by reduced proliferation, enhanced survival capability and increased stem 
cell and epithelial-mesenchymal transition (EMT) marker expression [117] (Fig. 3e). This cannibalistic behavior was also observed with A549 lung cancer cells, PANC-1 pancreatic cancer cells and PC-3 prostate cancer cells. Similarly, co-culture of PC3 cells with MSCs in either bone marrow media or endothelial media helped maintain cancer cells in a growth-arrested state but the inclusion of ECs with MSCs significantly enhanced tumor cell growth [118]. In contrast, co-culture of primary bone marrow stromal cells with breast cancer cells resulted in a supportive niche that enabled higher tumor cell proliferation and in vivo tumorigenesis while coculture of HS- 5 bone marrow stromal cells, hFOB osteoblasts and HUVECs with cancer cells resulted in an inhibitory niche that suppressed tumor cell growth and produced avascular, dormant tumors in mice [58]. Tumor dormancy was specifically induced by HS-5 and hFOB cells but not by HUVECs. The contrasting role of ECs in regulating tumor dormancy was best demonstrated in the study by Ghajar et al. where stable microvascular networks helped maintained tumor dormancy but sprouting neovasculature and endothelial tip cells promoted metastatic growth via secretion of periostin (POSTN) and transforming growth factor- $\beta$ (TGF $\beta-1)$. Adding to this complication, TGF $\beta-1$ is also known to show dual properties and can both induce and inhibit tumor dormancy in a context-dependent manner [42].

In addition to the bone marrow niche, the dormant liver microenvironment has also been modeled by inclusion of hepatocytes and non-parenchymal liver cells (NPCs) (Kupffer cells, sinusoidal endothelial cells and stellate cells) with breast cancer cells within an ex vivo microphysiological system [81, 105, 119]. Spontaneous dormancy of MDA-MB-231 and MCF7 cells was observed when cancer cells were introduced at very low densities (ratio of hepatocytes and NPCs to cancer cells >1000:1) [119] (Fig. 3d). Interestingly, inclusion of NPCs suppressed MDA-MB-231 growth but enhanced MCF7 growth, highlighting the differences in inherent tumor cell-intrinsic characteristics. Analysis of the cell secretome revealed specific cell-type differences (MDA-MB-231 cells: increased cancer attenuator follistatin and reduced pro-inflammatory cytokines IGFBP-1, MCP-1, MIP-1 $\alpha$, IL-6; MCF7: increased cancer signals osteopontin, sHER-2, VEGF-A, uPA, EGF amongst others). These analyses approaches could provide both prognostic and diagnostic markers of the dormant tumor behavior that could help guide future drug discovery initiatives.

Other organotropic niches modeled for tumor dormancy studies include breast cancer, bladder cancer, prostate cancer and lung cancer [104, 120]. In some cases, tumor dormancy can be induced simply by co-culturing breast, bladder or prostate cancer with respective stromal cells/fibroblasts on an adhesion-limited substrate and coaxing the cells to form 3D spheroids as demonstrated by Pavan et al. [120]. However, more intricate approaches involve tri-culture and differentiation of cell types within microfabricated devices to mimic more complex physiological structures. In one model of lung cancer dormancy, human lung microvascular cells were cultured under flow to form a uniform patent lumen with a layer of differentiated human primary airway epithelial cells or human primary alveolar epithelial cells to mimic the airway epithelium or alveolar epithelium respectively. H1975 non-small cell lung carcinoma (NSCLC) cells were seeded at low densities (>100:1 epithelial cells: cancer cells) to maintain low proliferation, spreading and invasion over 3-4 weeks in culture [104]. Overall, these examples demonstrate that recapitulation of organ-specific niches that suppress tumor growth and promote tumor cell quiescence is quite achievable in engineered constructs and microphysiological systems, provided that secondary cell types are presented in the right context and environmental conditions.

In conjunction with direct cell-cell contact and cell-secreted soluble factor signaling, tumor dormancy is also mediated by exosomal- and miRNA-based regulation, specifically between bone marrow MSCs and breast cancer cells [121-126]. MSC-derived exosomes were found to be responsible for horizontal transfer of miR-23b in bone marrow-metastatic BM2 breast cancer cells, which led to suppressed proliferation, reduced stem cell marker expression, reduced matrix invasion and sensitivity to docetaxel, by suppression of the target gene MARCKS [122]. The effect of exosomes from naïve and tumor-educated MSCs on breast cancer cell lines has also been examined. Tumor-primed MSC exosomes were more effective at inducing cycling quiescence and $\mathrm{G}_{0} / \mathrm{G}_{1}$ arrest in MDA-MB-231 cells, but not T47D cells, via transfer of miR-222/223 [121]. Exosomes derived from poorly-metastatic tumors can also initiate an innate immune response via recruitment of patrolling monocytes, NK cells and macrophages leading to suppression of distant metastasis [127].

These differences highlight the complex nature of inter-cellular interactions through parallel mechanisms and inherent tumor-intrinsic variations, which makes it challenging to generalize or predict molecular mechanisms underlying tumor dormancy. Engineered in vitro systems may provide the opportunity to elucidate the underlying mechanisms that mediate dormancy induction via direct cell-cell contact or soluble factors secreted from secondary cells.

\section{Biochemical-induced dormancy}

Modulation of the secondary organ-mimetic milieu via biochemical cues has been applied toward induction of tumor dormancy in several studies. These cues include induction of hypoxia, inhibition of nutrient diffusion, 
and addition/removal of soluble factors, either to inhibit cell-intrinsic pro-tumorigenic mechanisms or to inhibit downstream cell-cell and cell-matrix interactions [92, 128, 129]. Hypoxia plays a 'Janus'-like role in the tumor dormancy program, particularly in angiogenic dormancy. Chronic or diffusion-limited hypoxia can lead to increased expression of vascular endothelial growth factor (VEGF), TGF- $\beta$, platelet derived growth factor (PDGF), urokinase-type plasminogen activator (uPA) and other factors which upregulate angiogenic sprouting, promote matrix invasion and ultimately lead to metastatic growth. However, hypoxia can also induce apoptosis via multiple hypoxia inducible factor- $1 \alpha$ (HIF- $1 \alpha)$ dependent and independent pathways, which may regulate single cell dormancy [130, 131]. Hence, finding the optimum balance between these opposing processes in a context-dependent manner is necessary to maintain tumor dormancy in in vitro models.

Interestingly, some cancer cells may enter into a hypoxia-mediated dormancy program to survive in a stressful microenvironment. AsPC-1, a pancreatic cancer cell line, when maintained under chronic $1 \% \mathrm{O}_{2}$ hypoxia underwent reduced proliferation, cell death and ATP turnover with an altered AKT-dependent metabolic program while MDA-MB-231 cells underwent $G_{0} / G_{1}$ arrest with reduced metabolism and increased expression of stem-cell markers [132, 133]. Hypoxia in the primary tumor microenvironments of human head and neck squamous cell carcinoma (HNSCC) and triple negative breast cancers (TNBC) can also give rise to a subset of dormant cells in mouse, patient-derived xenografts (PDXs) and human tumors [134]. Induction of hypoxia can be achieved in a number of different ways: addition of iron-binding/substituting agents that inhibit HIF- $1 \alpha$ degradation and stabilize its cytosolic expression, and imposition of diffusion-limited hypoxic gradients (Fig. 3h). In one study, microfabricated nano-intravital devices (iNANIVIDs) loaded with desferrioxamine were implanted in T-HEp3 tumors grown in a CAM model to induce hypoxia from 4 hours to 3 days post-implantation [134]. Alternatively, cobalt chloride added to culture media of MCF7, MDA-MB-231 and OVCAR-3 cells induced hypoxia and resulted in similar dormancy responses as cells maintained in $0.1 \% \mathrm{O}_{2}$ conditions in both $2 \mathrm{D}$ culture and 3D collagen gels [129] (Fig. 3g). Breast, prostate and colon cancer cells encapsulated in Col-Tgel (collagen crosslinked with transglutaminase) hydrogels underwent diffusion-limited hypoxia over 9 days imposed by the 3D matrix which led to restricted cell proliferation, smaller clusters and cellular quiescence/necrosis [128]. Overall, hypoxia-mediated induction of the tumor dormancy program is a potential approach for investigating dynamic regulation occurring in both primary and disseminated tumor microenvironments.
Aside from hypoxia, soluble factor-mediated regulation of tumor dormancy has also been investigated. The most common approach is limiting growth factor mediated signaling in tumor cells by culturing cells in serum-free or low-serum media $[87,88]$. Although this method does induce cellular quiescence and restricted growth, the exact factors mediating this response can be difficult to elucidate. Fibroblast growth factor-2 (FGF-2), found abundantly expressed in the bone marrow stroma, has been used to induce dormancy in several breast cancer cell lines [135-140] (Fig. 3i). Barrios et al. found that FGF-2 regulates partial re-differentiation in some breast cancer cell lines, reduces motility and invasion, upregulates $\alpha_{5} \beta_{1}$ integrin expression and induces pro-survival characteristics through the PI3K/AKT signaling pathway. $\alpha_{5} \beta_{1}$ integrin ligation with fibronectin in the bone marrow stroma also independently regulated tumor dormancy [137]. Other factors found to induce tumor dormancy include 5-azadeoxycytidine (5-Aza-C), a DNA methylating agent, and retinoic acid, as shown by Sosa et al. [141]. The vitamin A-retinoic acid complex is known to regulate dormancy of hematopoietic stem cells in the bone marrow niche [142, 143]. An 'epigenetic therapy' of 5-Aza-C and retinoic acid was found to upregulate a master receptor, NR2F1, which induced quiescence in cancer cells via upregulation of pluripotency genes SOX9, RAR $\beta$ and NANOG [141]. Administration of specific anti-angiogenic agents (e.g. angiostatin, thrombospondin) could also limit angiogenic growth near dormant tumor sites and prolong pre-angiogenic dormancy $[42,144,145]$. These strategies could potentially be adopted in in vitro dormancy models, keeping in mind the context-dependency of tumor cell lines.

\section{Drug-induced dormancy}

Therapy-induced tumor dormancy has been a rising challenge in addressing metastatic recurrence due to the chemoresistant nature of dormant tumor cells $[73,146]$. Drug treatment of cancer cells in vitro and in vivo has been conducted in several studies to model therapy-induced dormancy observed in clinical settings [81, 95, 134, 147, 148]. Chemotherapeutics known to induce tumor dormancy in vivo and in patients include doxorubicin, docetaxel, cyclophosphamide, 5-fluorouracil (5-FU), methotrexate, cisplatin, bevacizumab, and trastuzumab [12, 149-153]. Similarly, some of these drugs used in in vitro models include doxorubicin, docetaxel, 5-FU, carboplatin amongst others [81, 95, 147, 148, 150] (Fig. 3j-k). The effect of doxorubicin administered to MDA-MB-231 cells in an engineered hepatic niche was evaluated by comparative analysis of the cytokine profile of growing, and dormant tumor populations, which revealed important similarities (Fraktalkine, RANTES, MCP-2, GM-CSF) and differences (VEGF-A, IL-12p70, IL-7, PECAM-1) in expression levels 
[81]. Associated effects of drug-induced tumor dormancy include enrichment of cells expressing stem-cell like characteristics and other clonal sub-populations, enhanced survival upon removal of treatment and an imbalance of pro- and anti-survival mechanisms [147, 148, 152].

Interestingly, metronomic chemotherapy regimens (drugs administered at regular, frequent doses to maintain a low, but active, range of drug concentrations over long time periods at low toxicity levels) have been proposed as an approach to induce angiogenic tumor dormancy [153-156]. Drugs that suppress HIF-1 $\alpha$ expression (e.g. topotecan, irinotecan, Adriamycin) or VEGF expression (irinotecan, 5-FU, oxaliplatin, paclitaxel and docetaxel) in different cancer cell lines could possibly be administered metronomically to suppress angiogenic outgrowth and prolong angiogenic dormancy. Overall, several strategies for inducing dormancy programs via drug treatment remain to be explored and adopted in in vitro engineered models.

\section{In vitro models of metastatic recurrence/relapse}

The main challenge in preventing metastatic recurrence or relapse is the presence of drug-tolerant persister sub-populations and quiescent cells that exhibit a high degree of EMT plasticity and cancer stemness, thereby enabling survival under stressful and harsh microenvironments through activation of pro-survival mechanisms [157-159]. Very often, clonal populations expanded from these drug-selected sub-populations exhibit a higher degree of chemoresistance and need to be targeted via alternate mechanisms. Multiple factors including stromal and endothelial cell signaling and surgery-induced inflammation have been implicated toward triggering the metastatic growth from dormant tumor cells [9, 160, 161] (Fig. 4). Several in vitro models simulating this phase of tumor evolution have been developed and various techniques have been employed to induce reactivation of 3D encapsulated dormant cancer cells.

One prominent approach of studying metastatic relapse using in vitro biomaterial-based models is through spatiotemporal modulation of the engineered matrix [88, 89, 162, 163]. Modulation of matrix characteristics can be achieved by partial enzymatic digestion of a confining restrictive matrix, thereby lowering stiffness and crosslinking density and allowing encapsulated dormant cells more freedom to proliferate and invade the surrounding matrix [89]. Alternatively, cells can be completely extracted from the confining matrix (and potentially re-embedded in a soft, permissive matrix) to induce a proliferative switch from a quiescent state [88, 89]. 3D spheroids containing dormant tumor cells, when transferred to a more adhesive substrate, demonstrated higher cell dissemination and spreading [120]. Integrin engagement of dormant cancer cells with specific ECM proteins (fibronectin, versican,
tenascin-C, collagen-I) can also promote metastatic relapse $[42,162]$. Barkan et al. demonstrated that dormant D2.0R mouse mammary cancer cells overexpressing integrin $\beta_{1}$ in a collagen-I-rich fibrotic matrix leads to phosphorylation of SRC, FAK and MLC, activation of ERK, actin stress fiber formation, and cancer cell spreading [162]. These studies demonstrate that multiple approaches can be employed to modulate matrix characteristics ultimately leading to activation of proliferation in dormant cancer cells.

Other approaches for investigating the dormancy-proliferation switch involve direct stimulation of dormant tumor cells via pro-inflammatory cytokines and angiogenic growth factors, indirect paracrine signaling from activated/inflamed secondary cells, and termination of chemotherapeutic/hypoxic challenge amongst others [42, 58, 59, 81, 129, 139, 140, 148, 164]. Some common pro-inflammatory cytokines used to induce proliferation and invasion of cancer cells include lipopolysaccharide (LPS), epidermal growth factor (EGF), tumor necrosis factor $\alpha(\mathrm{TNF} \alpha)$, interleukin $\beta$ (IL- $\beta$ ), interleukin 6 (IL-6) and prostaglandin E2 (PGE2) [81, 139]. Insulin-like growth factor 1 (IGF1) was found to initiate self-renewal of lung cancer stem cells in dormant lung tumors via the activation of a PI3K/Akt/ $\beta$-catenin pathway and production of the angiogenic factors chemokine (C-X-C motif) ligand 1 (CXCL1) and placental growth factor (PIGF) [59]. Periostin and TGF $\beta-1$ secretion from sprouting neovasculature promoted metastatic growth in dormant colonies of breast cancer cells in engineered lung and bone marrow stromal matrices [42]. Small molecule inhibition of specific factors (p38 MAPK, Alk5 and receptor tyrosine kinases) associated with dormancy pathways have also been used to reverse the inhibition of cell-cycle arrest in quiescent cancer cells and promote proliferation [58].

Stromal cells, activated by pro-inflammatory cytokines, oxidative stress or estrogen deprivation, can indirectly stimulate dormant cancer toward a proliferative state [139]. Paracrine signaling from stromal cells can also occur via horizontal transfer of mitochondrial DNA (from cancer-associated fibroblasts) via extracellular vesicles (EVs), induction of oxidative phosphorylation and an exit from dormancy [164]. Considering that exosomes and EVs from the primary tumor and secondary niche cells can regulate the pre-metastatic niche, favoring tumor growth, they can also be surmised to influence the dormancy-proliferative switch via undiscovered mechanisms [165-170]. Multiple approaches for investigating the dormancy/proliferation switch exist and they can be applied in a context dependent-manner in engineered in vitro models to investigate the molecular mechanisms underlying tumor recurrence and provide potential targets for therapeutic intervention. 


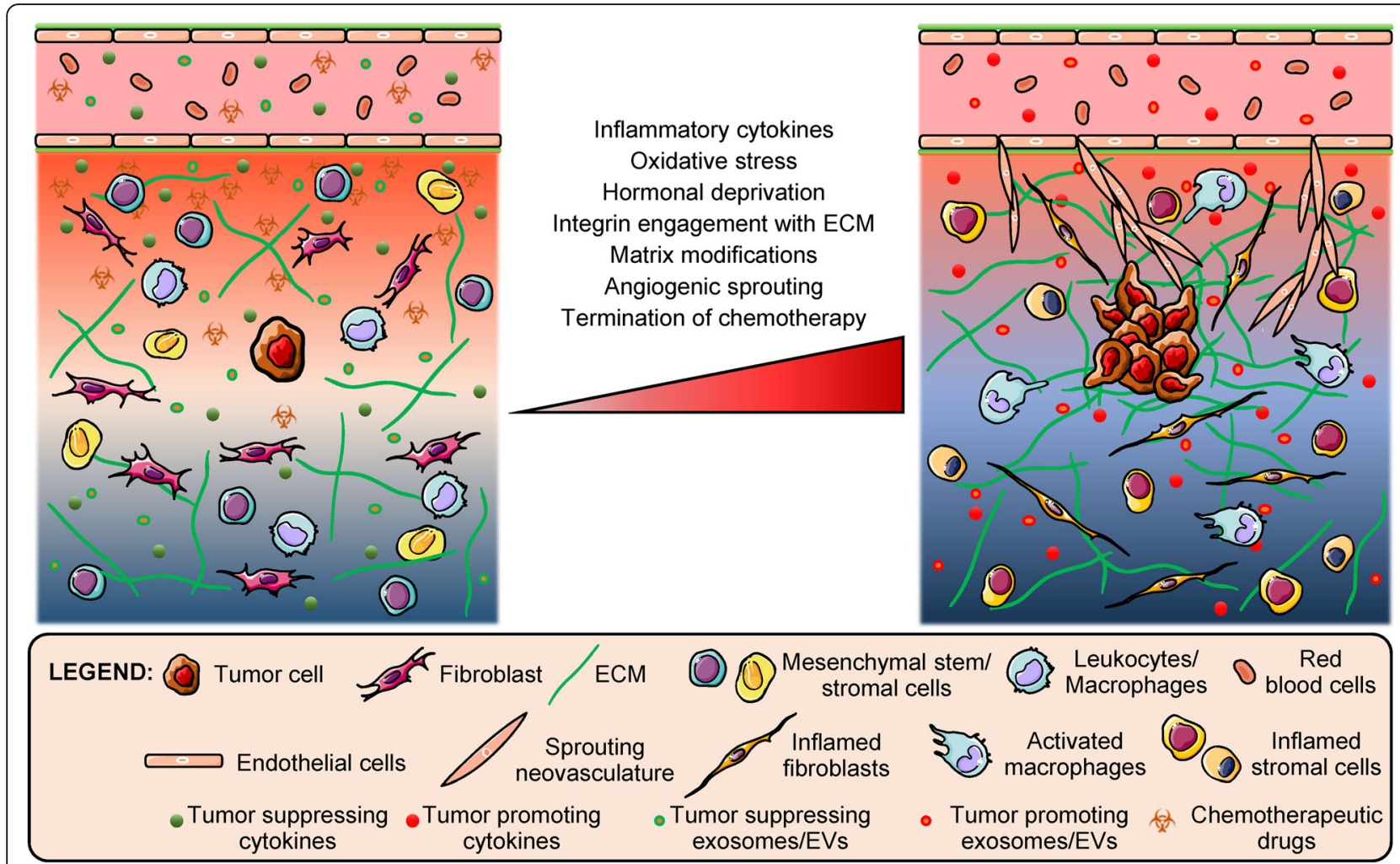

Fig. 4 Factors influencing reactivation of dormant cancer cells. Dormant tumor cells in the secondary niche can be stimulated or triggered toward metastatic growth via multiple sources including pro-inflammatory and angiogenic factors, paracrine signaling by stromal cells and sprouting vasculature, and dysregulated cell-matrix interactions amongst others

\section{Therapeutic strategies for tumor dormancy}

A majority of FDA approved anti-cancer therapeutics are targeted towards inhibiting cell proliferation, inducing cell cycle arrest and cell death [171]. However, dormant tumor cells (exhibiting low proliferation, cellular quiescence, high clonal heterogeneity) can be difficult to treat using these therapeutics. One comparative study demonstrated that conventional drugs including paclitaxel, doxorubicin, and 5-FU eliminate 2D cultured cells with high Ki67 expression; but lose their respective efficacy against the same cell types when cultured as 3D spheroids [172]. Additionally, diverse drug-resistance mechanisms can evolve from individual persister drug-tolerant cells, thereby necessitating synergistic targeting approaches for effective treatment of heterogeneous clones [157]. Hence, efforts are underway to discover novel targets, signaling pathways and therapeutic strategies to treat slow-cycling sub-populations and minimal residual disease as pre-emptive measures to eliminate dormant tumor cells [86, 173-175].

Toward this end, high-throughput drug screening studies have revealed potential mechanisms employed by cancer cells to survive chemotherapeutic insult and to develop alternate targeting strategies to enhance quiescent cell death [176-178]. MDA-MB-231 cells (in co-culture with HS-5 bone marrow stromal cells) treated with doxorubicin were able to survive through compensatory action of the MEK pathway and Cavnar et al. demonstrated that use of MEK inhibitors as synergistic agents selectively induced death in cancer cells compared to stromal cells [179]. A drug response-based gene expression profiling study on colon cancer cell lines revealed that quiescent cells in 3D spheroids exhibit upregulated cholesterol biosynthesis and mevalonate pathway genes that can be synergistically targeted with statins (simvastatin, Atorvastatin: cholesterol-lowering drugs, inhibitors of the mevalonate pathway) and oxidative phosphorylation inhibitors (nitazoxanide, salinomycin, antimycin A, FCCP, oligomycin A) [178]. Similarly, using respiratory chain inhibitors (metformin, antimycin A) against breast, prostate, and colon cancer spheroids in conjunction with cytostatic agents (paclitaxel, cisplatin) helped eliminate proliferative as well as dormant sub-populations within the spheroids, leading to low spheroid viability [177]. Interestingly, co-administration of cytochalasin B or 2-deoxy-D-glucose, inhibitors of cellular glucose uptake or glycolysis respectively, led to complete death of tumor spheroids indicating that glucose concentration in the surrounding microenvironment also confers some degree of resistance [177]. 
Another high throughput screening study revealed two potential hits against dormant micrometastasis in MDA-MB-435 cells grown on SISgel (obtained from ECM of small intestine submucosa) [176]. An extensive algorithmic search of similar compounds revealed potential targets which include matrix metalloproteinases, protein-tyrosine phosphatase, carbonic anhydrases and adenosine A1/A2/A3 receptors amongst others. Inducing chronic endoplasmic reticulum (ER) stress using thapsigargin (a SERCA inhibitor) combined with bortezomib (a proteasome inhibitor) also caused significant cell death in dormant breast and bladder cancer spheroids via protein misfolding and inhibition of an anti-apoptotic survival pathway [120]. Subsequent RNA-sequencing of dormant cells revealed upregulated ribosomal protein genes (protein translation) and pro-apoptotic protein-coding genes which could also provide additional targets for future dormancy-specific drugs [120].

Although high-throughput drug screening has traditionally been conducted on 2D cultured cells or 3D spheroids in well plates, the translation of novel in vitro dormancy models to a high-throughput format is of great interest. The high degree of control and uniformity presented in simplistic in vitro models make them amenable for high-throughput analysis. However, incorporation of complex elements of the dormant niche (including stromal cells, endothelial cells, ECM proteins, growth factors) could potentially prove challenging with respect to scale-up. Toward this goal, Kenny et al. demonstrated screening of $>2400$ drug compounds against metastatic ovarian cancer cells in a 3D organotypic culture that included mesothelial cells and fibroblasts in a fibronectin and collagen I-rich ECM [180]. A similar approach could potentially be extended for use with other engineered biomaterials and existing platforms. However, integration of microfluidic organ-on-a-chip systems with established high-throughput screening platforms is still challenging owing to technical complexities of maintaining dynamic fluidic perfusion, continuous and end point readouts, and high variability in dynamic culture systems.

Targeting cell-matrix interactions in dormant niches has also been tested with one study reporting that administration of flavopiridol selectively abrogated dormant clones of MCF7 and T47D breast cancer cells via suppression of integrins $\alpha_{5}$ and $\beta_{1}$, reduced adhesion to fibronectin, diminished Akt phosphorylation and total protein levels of ERK1/2 and p38 [181, 182]. Additional treatment with MEK inhibitors or p38 inhibitors caused further reduction in dormant clones for both cell types, indicating that multiple pathways need to be targeted in parallel to achieve reasonable efficacies [181]. Inhibition of ERK1/2 phosphorylation, MAPK signaling, suppression of $\mathrm{UPA}$ receptor expression along with upregulation of p38 $\alpha / \beta$ expression and phosphorylation could be adopted as a strategy for inducing dormancy programs in multiple cancer cell types [183-185].

Additional therapeutic approaches toward preventing reactivation of dormant cells, metastatic relapse, and prolonging of the dormancy state are also being developed. Most prominent amongst them are suppression of cell-matrix interactions promoting adhesion, invasion and migration, EMT, angiogenic growth, inflammatory signaling, cancer stemness, and immunoediting of specific immune cell types (NK cells, myeloid derived suppressor cells) [72, 186-189]. For example, an in silico phenotype screen against several breast cancer cell lines identified alprostadil and haloperidol as anti-metastatic agents capable of reducing membrane fluidity, cell motility and resulting EMT [186]. Some candidate agents which could potentially be used to prolong dormancy programs include metarrestin [190], canakinumab [188], cabozantinib [189], and metformin [191, 192], along with other repurposed FDA-approved drugs and those in clinical trials for tumor recurrence (as reviewed by Hurst et al.) [86]. The reviews by Ordóñez-Morán and Dittmer summarize key promising dormancy-associated targets in the complex metastatic microenvironment niches that have been verified in cancer cell lines and animal models with potential translatability to humans $[72,182]$. Some of these targets include the SRC family of kinases, STAT3, $\beta_{1}$ integrin, VCAM-1, CXCR4, JAG1, TGF $\beta 3$, and periostin amongst others. Modulation of metastasis suppressor proteins (chief among them BRMS1, KISS1) and associated genes could also provide a therapeutic strategy against metastatic relapse in multiple cancer types [53, 72, 75, 193].

From pre-clinical observations, targeting of pre-metastatic disease and dormant tumor cells appears promising and offers a longer window of opportunity than intervention therapy for overt disease. Further, targeting dormant clones may prevent these cells from establishing a micrometastatic niche and isolated dormant cells could be more vulnerable at this stage. However, from a clinical perspective, operating such proposed metastasis prevention and anti-dormancy trials in the adjuvant setting may be difficult owing to several challenges. Such trials would involve long-term monitoring of large cohorts of patients, which may exceed the regulatory patent protection periods. Enrollment of patients in cohorts needs to be carefully evaluated to identify those that are most at risk of recurrent disease. Current endpoints for cancer treatment need to be reconsidered to incorporate long-term patient benefits, safety and efficacy specifically against dormant cells and time to metastasis, rather than tumor shrinkage [182]. The review by Goddard et al. provides a summary of clinical trials pertinent to tumor dormancy including targeting agents for DTCs and dormancy-specific end point metrics [194]. 
Overall, substantial opportunities exist for discovery of dormancy-associated targets and employing in vitro models may significantly enhance the capability of screening large numbers of potential compounds. These models may also provide mechanistic insight into dormancy mechanisms that could be exploited to test the efficacy of different compounds against quiescent, slow-cycling cells and thereby strengthen the repertoire of the drug discovery pipeline.

\section{Conclusions and future perspectives}

Overall, the significance of tumor dormancy and metastatic relapse in the context of cancer research and treatment has been discussed. The lack of, and the need to develop, engineered, in vitro models of tumor dormancy has been presented. Current approaches adopted for modeling of tumor dormancy and metastatic relapse using engineered biomaterials and microfabrication techniques have been described. Some of the key mechanisms associated with dormancy and potential targets discovered using these in vitro models have also been presented.

Biomaterial-based cancer models have mostly been limited to investigation of tumorigenesis and metastasis thus far. However, the importance of tumor dormancy and metastatic recurrence is gradually becoming more apparent among the tissue engineering and biomaterials communities. Accordingly, more focus is being directed toward modeling of tumor dormancy via recapitulation of cellular quiescence, cell cycle arrest, and low proliferation within engineered platforms. However, significant gaps in knowledge still exist with regards to the molecular mechanisms governing tumor dormancy, variation among cancer types, contextual dependency with stromal microenvironments, and definition of standard biomarkers or cell states associated with the dormant phenotype. One major aspect of tumor dormancy that has been underexplored in vitro is the role of immune cells in regulating dormancy mechanisms and imbalances in immune regulation that may help tumor cells escape dormancy. With recent advances in engineering pre-metastatic niches and immune cell engineering, these cell types could be incorporated in biomaterial-based models to recapitulate immune-regulated tumor dormancy [110]. Humanized, implantable engineered niches that can be serially transplanted in mice and used for long-term investigation of disseminated tumor cells along with interactions with immune and stromal cells can provide significant insight into mechanisms of dormancy as well as reactivation [195].

As further investigations and discoveries in tumor dormancy biology are made over time, it is expected that in vitro engineered models will also be improved concurrently to recapitulate these disease states with a high degree of physiological context. These models could provide additional tools and platforms to biologists that could potentially culminate in development of dormancy-targeted drugs, thereby improving survival outcomes in patients.

\section{Abbreviations}

2D: Two-dimensional; 3D: Three-dimensional; 5-Aza-C: 5-Azadeoxycytidine; 5FU: 5-Fluorouracil; AKT: Protein Kinase B; ATP: Adenosine Triphosphate;

BMP4: Bone Morphogenetic Protein 4; BRMS1: Breast cancer-Metastasis Suppressor 1; CAM: Chick Chorioallantoic Membrane; Cdc42: Cell Division

Control Protein 42 homolog; CTC: Circulating Tumor Cell; CXCL1: Chemokine (C-X-C Motif) Ligand 1; CXCR4: C-X-C Chemokine Receptor 4; EC: Endothelial Cell; ECM: Extracellular Matrix; EdU: 5-Ethynyl-2'-Deoxyuridine; EGF: Epidermal Growth Factor; EMT: Epithelial-Mesenchymal Transition; ER: Endoplasmic Reticulum; ERK: Extracellular Regulated Kinase; EV: Extracellular Vesicles; FAK: Focal Adhesion Kinase; FCCP: Carbonyl Cyanide 4-(Trifluoromethoxy) Phenylhydrazone; FDA: Food and Drug Administration; FGF-2: Fibroblast Growth Factor 2; GFP: Green Fluorescent Protein; GM-CS: GranulocyteMacrophage Colony-Stimulating Factor; HIF-1a: Hypoxia Inducible Factor-1a; HNSCC: Head and Neck Squamous Cell Carcinoma; HUVEC: Human Umbilical Vein Endothelial Cell; IGF1: Insulin-like growth factor 1; IGFBP-1: Insulin Like Growth Factor Binding Protein 1; IL-6/7/12/ $\beta$ : Interleukin 6/7/12/ $\beta$; iNANIVID: Nano-Intravital Device; IPN: Interpenetrating Network; JAG1: Jagged1; LPS: Lipopolysaccharide; MAPK: Mitogen Activated Protein Kinase; MCP-1: Monocyte Chemoattractant Protein 1; MCP-2: Monocyte Chemoattractant Protein 2; MEK: Mitogen-Activated Protein Kinase Kinase; MIP-1a: Macrophage Inflammatory Protein 1a; miRNA: MicroRNA;

MLC: Myosin Light Chain; MSC: Mesenchymal Stem/Stromal Cell; MTT: 3-(4,5Dimethylthiazol-2-yl)-2,5-Diphenyltetrazolium Bromide; NK: Natural Killer Cell; NPC: Non-Parenchymal Cell; NSCLC: Non-Small Cell Lung Carcinoma;

PCL: Poly ( $\varepsilon$-Caprolactone); PDGF: Platelet Derived Growth Factor;

PDX: Patient Derived Xenograft; PECAM-1: Platelet Endothelial Cell Adhesion Molecule 1; PEG: Poly(Ethylene Glycol); PGE2: Prostaglandin E2; PI3K: Phosphoinositide 3-Kinase; PIGF: Placental Growth Factor; POSTN: Periostin; RANTES: Chemokine (C-C motif) Ligand 5; RFP: Red Fluorescent Protein; SERCA: Sarco/Endoplasmic Reticulum Ca ${ }^{2+}$-ATPase; sHER2: Soluble Human Epidermal Growth Factor Receptor 2; SRC: ProtoOncogene Tyrosine-Protein Kinase; STAT3: Signal Transducer and Activator of Transcription 3; Tet2: Tet Methylcytosine Dioxygenase 2; TGF- $\beta$ : Transforming Growth Factor $\beta$; TNBC: Triple Negative Breast Cancer; TNFa: Tumor Necrosis Factor A; uPA: Urokinase-Type Plasminogen Activator; VCAM-1: Vascular Cell Adhesion Molecule 1; VE-cadherin: Vascular Endothelial Cadherin; VEGFA: Vascular Endothelial Growth Factor A; ZO-1: Zona Occludens 1

\section{Acknowledgements}

Not applicable.

\section{Funding}

This work was supported by funding form the National Institutes of Health/ National Cancer Institute IMAT Program (R21CA214299), National Science Foundation (NSF) CAREER Award (1751797), Delaware Bioscience Center for Advanced Technology (12A00448), and the W. M. Keck Foundation (15A00396). John Sperduto is supported by a NSF IGERT Fellowship (1144726). Cindy Farino is supported by a Graduate Scholar Award provided by the University of Delaware.

\section{Availability of data and materials}

Data sharing not applicable to this article as no data-sets were generated or analyzed during the current study.

\section{Authors' contributions}

SP and JHS wrote and edited the manuscript. SP, JLS, and CJF prepared the figures and the tables. All authors read and approved the final manuscript.

Ethics approval and consent to participate

Not applicable.

Consent for publication

The manuscript is approved by all the authors for publication.

Competing interests

The authors declare that they have no competing interests. 


\section{Publisher's Note}

Springer Nature remains neutral with regard to jurisdictional claims in published maps and institutional affiliations.

\section{Author details}

'Department of Biomedical Engineering, University of Delaware, 150 Academy Street, 161 Colburn Lab, Newark, DE 19716, USA. ${ }^{2}$ Delaware Biotechnology Institute, 15 Innovation Way, Newark, DE 19711, USA. ${ }^{3}$ Department of Materials Science and Engineering, University of Delaware, 201 DuPont Hall, Newark, DE 19716, USA.

\section{Received: 3 October 2018 Accepted: 16 November 2018} Published online: 27 December 2018

\section{References}

1. Mariotto $A B$, Etzioni R, Hurlbert M, Penberthy L, Mayer M. Estimation of the number of women living with metastatic breast cancer in the United States. Cancer Epidemiol Biomarkers Prev. 2017;26(6):809-15.

2. Arneson TJ, Li S, Peng Y, Weinhandl ED, Blaes A, Cetin K, et al. Estimated number of prevalent cases of metastatic bone disease in the US adult population. Clin Epidemiol. 2012;87.

3. Fox BD, Cheung VJ, Patel AJ, Suki D, Rao G. Epidemiology of metastatic brain tumors. Neurosurg Clin N Am. 2011;22(1):1-6.

4. Ostrom QT, Wright CH, Barnholtz-Sloan JS. Brain metastases: epidemiology. In: Handbook of Clinical Neurology Elsevier; 2018. p. 27-42. isbn:978-0-12811161-1 ISSN: 0072-9752.

5. Chen M-T, Sun H-F, Zhao Y, Fu W-Y, Yang L-P, Gao S-P, et al. Comparison of patterns and prognosis among distant metastatic breast cancer patients by age groups: a SEER population-based analysis. Sci Rep. 2017;7:9254. https:// doi.org/10.1038/s41598-017-10166-8.

6. Demicheli R, Terenziani M, Bonadonna G. Estimate of tumor growth time for breast cancer local recurrences: rapid growth after wake-up? Breast Cancer Res Treat. 1998:51(2):133-7.

7. Uramoto H, Tanaka F. Recurrence after surgery in patients with NSCLC. Transl Lung Cancer Res. 2014:3(4):242-9.

8. Zhang XH-F, Giuliano M, Trivedi MV, Schiff R, Osborne CK. Metastasis dormancy in estrogen receptor-positive breast cancer. Clin Cancer Res. 2013;19(23):6389-97.

9. Krall JA, Reinhardt F, Mercury OA, Pattabiraman DR, Brooks MW, Dougan M, et al. The systemic response to surgery triggers the outgrowth of distant immune-controlled tumors in mouse models of dormancy. Sci Transl Med. 2018;10(436):eaan3464.

10. Lin W-C, Rajbhandari N, Wagner K-U. Cancer cell dormancy in novel mouse models for reversible pancreatic cancer: a lingering challenge in the development of targeted therapies. Cancer Res. 2014;74(8):2138-43.

11. Brackstone M, Townson JL, Chambers AF. Tumour dormancy in breast cancer: an update. Breast Cancer Res. 2007;9(3):208.

12. Demicheli R, Miceli R, Moliterni A, Zambetti M, Hrushesky WJM, Retsky MW, et al. Breast cancer recurrence dynamics following adjuvant CMF is consistent with tumor dormancy and mastectomy-driven acceleration of the metastatic process. Ann Oncol. 2005;16(9):1449-57.

13. Naumov GN, Townson JL, MacDonald IC, Wilson SM, Bramwell VHC, Groom $A C$, et al. Ineffectiveness of doxorubicin treatment on solitary dormant mammary carcinoma cells or late-developing metastases. Breast Cancer Res Treat. 2003:82(3):199-206.

14. Demicheli R, Retsky MW, Swartzendruber DE, Bonadonna G. Proposal for a new model of breast cancer metastatic development. Ann Oncol. 1997; 8(11):1075-80

15. Karrison TG, Ferguson DJ, Meier P. Dormancy of mammary carcinoma after mastectomy. J Natl Cancer Inst. 1999;91(1):80-5.

16. Marches $\mathrm{R}$, Scheuermann $\mathrm{R}$, Uhr J. Cancer dormancy: from mice to man. Cell Cycle. 2006;5(16):1772-8

17. Uhr JW, Pantel K. Controversies in clinical cancer dormancy. Proc Natl Acad Sci. 2011;108(30):12396-400.

18. Gomis RR, Gawrzak S. Tumor cell dormancy. Mol Oncol. 2017;11(1):62-78,

19. Meng S, Tripathy D, Frenkel EP, Shete S, Naftalis EZ, Huth JF, et al. Circulating tumor cells in patients with breast cancer dormancy. Clin Cancer Res. 2004;10(24):8152-62

20. Grzelak CA, Ghajar CM. Metastasis "systems" biology: how are macroenvironmental signals transmitted into microenvironmental cues for disseminated tumor cells? Curr Opin Cell Biol. 2017;48:79-86.
21. Bissell MJ, Hines WC. Why don't we get more cancer? A proposed role of the microenvironment in restraining cancer progression. Nat Med. 2011; 17(3):320-9.

22. El Touny LH, Barkan D, Green JE. The role of fibrosis in tumor progression and the dormant to proliferative switch. In: Hayat MA, editor. Tumor Dormancy, Quiescence, and Senescence, Volume 2. Dordrecht: Springer Netherlands; 2014. p. 155-164. ISBN 978-94-007-7726-2

23. Pantel $\mathrm{K}$, Brakenhoff RH. Dissecting the metastatic cascade. Nat Rev Cancer. 2004;4(6):448-56.

24. Steeg PS. Tumor metastasis: mechanistic insights and clinical challenges. Nat Med. 2006;12(8):895-904

25. Senft D, Ronai ZA. Adaptive stress responses during tumor metastasis and dormancy. Trends Cancer. 2016;2(8):429-42.

26. Chambers AF, Groom AC, MacDonald IC. Dissemination and growth of cancer cells in metastatic sites. Nat Rev Cancer. 2002;2(8):563-72.

27. Luzzi KJ, MacDonald IC, Schmidt EE, Kerkvliet N, Morris VL, Chambers AF, et al. Multistep nature of metastatic inefficiency: dormancy of solitary cells after successful extravasation and limited survival of early micrometastases. Am J Pathol. 1998:153(3):865-73.

28. Cameron MD, Schmidt EE, Kerkvliet N, Nadkarni KV, Morris VL, Groom AC, et al. Temporal progression of metastasis in lung: cell survival, dormancy, and location dependence of metastatic inefficiency. Cancer Res. 2000;60(9): 2541-6.

29. Taylor DP, Wells JZ, Savol A, Chennubhotla C, Wells A. Modeling boundary conditions for balanced proliferation in metastatic latency. Clin Cancer Res. 2013:19(5):1063-70.

30. Klein CA, Hölzel D. Systemic cancer progression and tumor dormancy: mathematical models meet single cell genomics. Cell Cycle. 2006;5(16): 1788-98.

31. Spiliotaki M, Mavroudis D, Kapranou K, Markomanolaki H, Kallergi G, Koinis F, et al. Evaluation of proliferation and apoptosis markers in circulating tumor cells of women with early breast cancer who are candidates for tumor dormancy. Breast Cancer Res. 2014;16(6):485. https://doi.org/10.1186/s13058014-0485-8.

32. Noltenius C, Noltenius H. Dormant tumor cells in liver and brain. An autopsy study on metastasizing tumors. Pathol-Res Pract. 1985;179(4-5): 504-11.

33. Uhr JW, Scheuermann RH, Street NE, Vitetta ES. Cancer dormancy: Opportunities for new therapeutic approaches. Nat Med. 1997;3(5):505-9.

34. Manjili MH. Tumor dormancy and relapse: From a natural byproduct of evolution to a disease state. Cancer Res. 2017;77(10):2564-9.

35. Bragado P, Sosa MS, Keely P, Condeelis J, Aguirre-Ghiso JA Microenvironments dictating tumor cell dormancy. In: Ignatiadis M, Sotiriou C, Pantel K, editors. Minimal Residual Disease and Circulating Tumor Cells in Breast Cancer. Berlin: Springer Berlin Heidelberg; 2012. p. 25-39. isbn:978-3642-28160-0.

36. Naumov GN, Folkman J, Straume O, Akslen LA. Tumor-vascular interactions and tumor dormancy. APMIS. 2008;116(7-8):569-85.

37. Folkman J, Kalluri R. Cancer without disease. Nature. 2004:427(6977):787.

38. Röcken M. Early tumor dissemination, but late metastasis: insights into tumor dormancy. J Clin Invest. 2010;120(6):1800-3.

39. Guba M, Cernaianu G, Koehl G, Geissler EK, Jauch KW, Anthuber M, et al. A primary tumor promotes dormancy of solitary tumor cells before inhibiting angiogenesis. Cancer Res. 2001;61(14):5575-9.

40. Castaño Z, San Juan BP, Spiegel A, Pant A, DeCristo MJ, Laszewski T, et al. IL$1 \beta$ inflammatory response driven by primary breast cancer prevents metastasis-initiating cell colonization. Nat Cell Biol. 2018 Sep;20(9):1084-97.

41. Peeters CFJM, de Waal RMW, Wobbes T, Ruers TJM. Metastatic dormancy imposed by the primary tumor: does it exist in humans? Ann Surg Oncol. 2008;15(11):3308-15.

42. Ghajar CM, Peinado $H$, Mori $H$, Matei IR, Evason KJ, Brazier $H$, et al. The perivascular niche regulates breast tumour dormancy. Nat Cell Biol. 2013; 15(7):807-17.

43. Klein CA. Parallel progression of primary tumours and metastases. Nat Rev Cancer. 2009;9(4):302-12

44. Payne KK, Keim RC, Graham L, Idowu MO, Wan W, Wang X-Y, et al. Tumorreactive immune cells protect against metastatic tumor and induce immunoediting of indolent but not quiescent tumor cells. J Leukoc Biol. 2016;100(3):625-35.

45. Aguirre-Ghiso JA. Models, mechanisms and clinical evidence for cancer dormancy. Nat Rev Cancer. 2007;7(11):834-46. 
46. Guadamillas MC, Cerezo A, del Pozo MA. Overcoming anoikis - pathways to anchorage-independent growth in cancer. J Cell Sci. 2011;124(19):3189-97.

47. Lu Z, Luo RZ, Lu Y, Zhang X, Yu Q, Khare S, et al. The tumor suppressor gene $A R H I$ regulates autophagy and tumor dormancy in human ovarian cancer cells. J Clin Invest. 2008;118(12):3917-29. https://doi.org/10.1172/ JCl35512.

48. Havas KM, Milchevskaya V, Radic K, Alladin A, Kafkia E, Garcia M, et al. Metabolic shifts in residual breast cancer drive tumor recurrence. J Clin Invest. 2017;127(6):2091-105.

49. van der Toom EE, Verdone JE, Pienta KJ. Disseminated tumor cells and dormancy in prostate cancer metastasis. Curr Opin Biotechnol. 2016;40:9-15.

50. Banys FT, Hartkopf K, Meier-Stiegen N, et al. Dormancy in breast cancer. Breast Cancer Targets Ther. 2012;4:183-91.

51. Naumov GN, MacDonald IC, Weinmeister PM, Kerkvliet N, Nadkarni KV, Wilson SM, et al. Persistence of solitary mammary carcinoma cells in a secondary site: a possible contributor to dormancy. Cancer Res. 2002;62(7):2162-8.

52. Kienast $Y$, von Baumgarten $L$, Fuhrmann M, Klinkert WEF, Goldbrunner $R$, Herms J, et al. Real-time imaging reveals the single steps of brain metastasis formation. Nat Med. 2010 Jan;16(1):116-22.

53. Hedley BD, Allan AL, Chambers AF. Tumor dormancy and the role of metastasis suppressor genes in regulating ectopic growth. Future Oncol. 2006;2(5):627-41.

54. Linde N, Fluegen G, Aguirre-Ghiso JA. The relationship between dormant cancer cells and their microenvironment. In: Advances in Cancer Research: Elsevier; 2016. p. 45-71. https://doi.org/10.1016/bs.acr.2016.07.002.

55. Townson JL, Chambers AF. Dormancy of solitary metastatic cells. Cell Cycle. 2006;5(16):1744-50.

56. Holmgren L, O'Reilly MS, Folkman J. Dormancy of micrometastases: balanced proliferation and apoptosis in the presence of angiogenesis suppression. Nat Med. 1995;1(2):149-53.

57. Almog N. Molecular mechanisms underlying tumor dormancy. Cancer Lett. 2010;294(2):139-46.

58. Marlow R, Honeth G, Lombardi S, Cariati M, Hessey S, Pipili A, et al. A novel model of dormancy for bone metastatic breast cancer cells. Cancer Res. 2013;73(23):6886-99.

59. Li L, Li J-C, Yang H, Zhang X, Liu L-L, Li Y, et al. Expansion of cancer stem cell pool initiates lung cancer recurrence before angiogenesis. Proc Natl Acad Sci. 2018;115(38):E8948-57.

60. Kusumbe AP, Bapat SA. Cancer stem cells and aneuploid populations within developing tumors are the major determinants of tumor dormancy. Cancer Res. 2009;69(24):9245-53.

61. Izraely S, Sagi-Assif O, Klein A, Meshel T, Tsarfaty G, Pasmanik-Chor M, et al. The metastatic microenvironment: brain-residing melanoma metastasis and dormant micrometastasis. Int J Cancer. 2012;131(5):1071-82.

62. Naumov GN, Bender E, Zurakowski D, Kang S-Y, Sampson D, Flynn E, et al. A model of human tumor dormancy: an angiogenic switch from the nonangiogenic phenotype. J Natl Cancer Inst. 2006:98(5):316-25.

63. Indraccolo S, Stievano L, Minuzzo S, Tosello V, Esposito G, Piovan E, et al. Interruption of tumor dormancy by a transient angiogenic burst within the tumor microenvironment. Proc Natl Acad Sci U S A. 2006;103(11):4216-21.

64. Gimbrone MA, Leapman SB, Cotran RS, Folkman J. Tumor dormancy in vivo by prevention of neovascularization. J Exp Med. 1972;136(2):261-76.

65. Ranganathan AC, Adam AP, Aguirre-Ghiso JA. Opposing roles of mitogenic and stress signaling pathways in the induction of cancer dormancy. Cell Cycle. 2006:5(16):1799-807.

66. Gay LJ, Malanchi I. The sleeping ugly: Tumour microenvironment's act to make or break the spell of dormancy. Biochim Biophys Acta - Rev Cancer. 2017;1868(1):231-8.

67. Naumov GN, Akslen LA, Folkman J. Role of angiogenesis in human tumor dormancy: Animal models of the angiogenic switch. Cell Cycle. 2006;5(16): 1779-87.

68. Paez D, Labonte MJ, Bohanes P, Zhang W, Benhanim L, Ning Y, et al. Cancer dormancy: A model of early dissemination and late cancer recurrence. Clin Cancer Res. 2012;18(3):645-53.

69. Wikman H, Vessella R, Pantel K. Cancer micrometastasis and tumour dormancy. APMIS. 2008;116(7-8):754-70.

70. Favaro E, Amadori A, Indraccolo S. Cellular interactions in the vascular niche: implications in the regulation of tumor dormancy. APMIS. 2008;116(7-8): 648-59.

71. Giancotti FG. Mechanisms governing metastatic dormancy and reactivation. Cell. 2013;155(4):750-64.
72. Dittmer J. Mechanisms governing metastatic dormancy in breast cancer. Semin Cancer Biol. 2017:44:72-82.

73. Sosa MS, Bragado P, Aguirre-Ghiso JA. Mechanisms of disseminated cancer cell dormancy: an awakening field. Nat Rev Cancer. 2014;14(9):611-22.

74. Barkan D, Chambers AF. Prevention of conversion of tumor dormancy into proliferative metastases. In: Cote RJ, Datar RH, editors. Circulating Tumor Cells. New York: Springer New York; 2016. p. 121-37. https://doi.org/10. 1007/978-1-4939-3363-1. isbn:978-1-4939-3363-1.

75. Horak CE, Lee JH, Marshall J-C, Shreeve SM, Steeg PS. The role of metastasis suppressor genes in metastatic dormancy. APMIS. 2008;116(7-8):586-601.

76. Yadav AS, Pandey PR, Butti R, Radharani NNV, Roy S, Bhalara SR, et al. The biology and therapeutic implications of tumor dormancy and reactivation. Front Oncol. 2018;8. https://doi.org/10.3389/fonc.2018.00072.

77. Barkan D, Green JE, Chambers AF. Extracellular matrix: A gatekeeper in the transition from dormancy to metastatic growth. Eur J Cancer. 2010;46(7): 1181-8

78. Pontier SM, Muller WJ. Integrins in breast cancer dormancy. APMIS. 2008; 116(7-8):677-84

79. Zhang XH-F, Jin X, Malladi S, Zou Y, Wen YH, Brogi E, et al. Selection of bone metastasis seeds by mesenchymal signals in the primary tumor stroma. Cell. 2013;154(5):1060-73.

80. Gómez-Cuadrado L, Tracey N, Ma R, Qian B, Brunton VG. Mouse models of metastasis: progress and prospects. Dis Model Mech. 2017;10(9):1061-74

81. Clark AM, Kumar MP, Wheeler SE, Young CL, Venkataramanan R, Stolz DB, et al. A model of dormant-emergent metastatic breast cancer progression enabling exploration of biomarker signatures. Mol Cell Proteomics. 2018; 17(4):619-30.

82. Hong H, Yang Y, Zhang Y, Cai W. Non-invasive cell tracking in cancer and cancer therapy. Curr Top Med Chem. 2010;10(12):1237-48.

83. Voura EB, Jaiswal JK, Mattoussi H, Simon SM. Tracking metastatic tumor cell extravasation with quantum dot nanocrystals and fluorescence emissionscanning microscopy. Nat Med. 2004;10(9):993-8.

84. Entenberg D, Voiculescu S, Guo P, Borriello L, Wang Y, Karagiannis GS, et al. A permanent window for the murine lung enables high-resolution imaging of cancer metastasis. Nat Methods. 2017;15(1):73-80.

85. Koop S, MacDonald IC, Luzzi K, Schmidt EE, Morris VL, Grattan M, et al. Fate of melanoma cells entering the microcirculation: over $80 \%$ survive and extravasate. Cancer Res. 1995:55(12):2520-3.

86. Hurst RE, Bastian A, Bailey-Downs L, Ihnat MA. Targeting dormant micrometastases: rationale, evidence to date and clinical implications. Ther Adv Med Oncol. 2016;8(2):126-37.

87. Reynolds DS, Bougher KM, Letendre JH, Fitzgerald SF, Gisladottir UO, Grinstaff MW, et al. Mechanical confinement via a PEG/Collagen interpenetrating network inhibits behavior characteristic of malignant cells in the triple negative breast cancer cell line MDA.MB.231. Acta Biomater. 2018;77:85-95.

88. Preciado JA, Reátegui E, Azarin SM, Lou E, Aksan A. Immobilization platform to induce quiescence in dormancy-capable cancer cells. Technology. 2017; 05(03):129-38.

89. Fang JY, Tan S-J, Wu Y-C, Yang Z, Hoang BX, Han B. From competency to dormancy: a 3D model to study cancer cells and drug responsiveness. J Transl Med. 2016;14(1). https://doi.org/10.1186/s12967-016-0798-8.

90. Pradhan S, Chaudhury CS, Lipke EA. Dual-phase, surface tension-based fabrication method for generation of tumor millibeads. Langmuir. 2014; 30(13):3817-25.

91. Helmlinger G, Netti PA, Lichtenbeld HC, Melder RJ, Jain RK. Solid stress inhibits the growth of multicellular tumor spheroids. Nat Biotechnol. 1997; 15(8):778-83.

92. Pradhan S, Hassani I, Seeto WJ, Lipke EA. PEG-fibrinogen hydrogels for three-dimensional breast cancer cell culture. J Biomed Mater Res A. 2017; 105(1):236-52

93. Cheng G, Tse J, Jain RK, Munn LL. Micro-environmental mechanical stress controls tumor spheroid size and morphology by suppressing proliferation and inducing apoptosis in cancer cells. Blagosklonny MV, editor. PLoS ONE. 2009;4(2):e4632

94. Keeratichamroen S, Lirdprapamongkol K, Svasti J. Mechanism of ECMinduced dormancy and chemoresistance in A549 human lung carcinoma cells. Oncol Rep. 2018. https://doi.org/10.3892/or.2018.6258.

95. Guiro K, Patel SA, Greco SJ, Rameshwar P, Arinzeh TL. Investigating breast cancer cell behavior using tissue engineering scaffolds. Pisignano D, editor. PLOS ONE. 2015;10(4):e0118724. 
96. Pogány G, Timár F, Oláh J, Harisi R, Polony G, Paku S, et al. Role of the basement membrane in tumor cell dormancy and cytotoxic resistance. Oncology. 2001;60(3):274-81.

97. Sapudom J, Rubner S, Martin S, Kurth T, Riedel S, Mierke CT, et al. The phenotype of cancer cell invasion controlled by fibril diameter and pore size of 3D collagen networks. Biomaterials. 2015;52:367-75.

98. Pradhan S, Smith AM, Garson CJ, Hassani I, Seeto WJ, Pant K, et al. A microvascularized tumor-mimetic platform for assessing anti-cancer drug efficacy. Sci Rep 2018;8(1). DOl: https://doi.org/10.1038/s41598-018-21075-9

99. Chen CS, Mrksich M, Huang S, Whitesides GM, Ingber DE. Geometric control of cell life and death. Science. 1997;276(5317):1425-8.

100. Liu J, Tan Y, Zhang H, Zhang Y, Xu P, Chen J, et al. Soft fibrin gels promote selection and growth of tumorigenic cells. Nat Mater. 2012;11(8):734-41.

101. Liu Y, LV J, Liang X, Yin X, Zhang L, Chen D, et al. Fibrin stiffness mediates dormancy of tumor-repopulating cells via a Cdc42-driven Tet2 epigenetic program. Cancer Res. 2018;78(14):3926-37.

102. Desmaison A, Guillaume L, Triclin S, Weiss P, Ducommun B, Lobjois V. Impact of physical confinement on nuclei geometry and cell division dynamics in 3D spheroids. Sci Rep. 2018;8(1). https://doi.org/10.1038/ s41598-018-27060-6.

103. Tse HTK, Weaver WM, Di Carlo D. Increased asymmetric and multi-daughter cell division in mechanically confined microenvironments. Lam W, editor. PLoS ONE. 2012;7(6):e38986.

104. Hassell BA, Goyal G, Lee E, Sontheimer-Phelps A, Levy O, Chen CS, et al. Human organ chip models recapitulate orthotopic lung cancer growth, therapeutic responses, and tumor dormancy in vitro. Cell Rep. 2017;21(2): 508-16.

105. Clark AM, Wheeler SE, Young CL, Stockdale L, Shepard Neiman J, Zhao W, et al. A liver microphysiological system of tumor cell dormancy and inflammatory responsiveness is affected by scaffold properties. Lab Chip. 2017;17(1):156-68.

106. Ghajar CM. Metastasis prevention by targeting the dormant niche. Nat Rev Cancer. 2015;15(4):238-47.

107. Boyerinas B, Zafrir M, Yesilkanal AE, Price TT, Hyjek EM, Sipkins DA. Adhesion to osteopontin in the bone marrow niche regulates lymphoblastic leukemia cell dormancy. Blood. 2013;121(24):4821-31.

108. Lathia JD, Gallagher J, Heddleston JM, Wang J, Eyler CE, Macswords J, et al. Integrin alpha 6 regulates glioblastoma stem cells. Cell Stem Cell. 2010;6(5): 421-32.

109. Lathia JD, Li M, Hall PE, Gallagher J, Hale JS, Wu Q, et al. Laminin alpha 2 enables glioblastoma stem cell growth. Ann Neurol. 2012;72(5):766-78.

110. Albrengues J, Shields MA, Ng D, Park CG, Ambrico A, Poindexter ME, et al. Neutrophil extracellular traps produced during inflammation awaken dormant cancer cells in mice. Science. 2018:361(6409):eaao4227.

111. Walker ND, Patel J, Munoz JL, Hu M, Guiro K, Sinha G, et al. The bone marrow niche in support of breast cancer dormancy. Cancer Lett. 2016;380(1):263-71.

112. Decker AM, Jung Y, Cackowski F, Taichman RS. The role of hematopoietic stem cell niche in prostate cancer bone metastasis. J Bone Oncol. 2016;5(3): $117-20$

113. Rameshwar P. Breast cancer cell dormancy in bone marrow: potential therapeutic targets within the marrow microenvironment. Expert Rev Anticancer Ther. 2010;10(2):129-32.

114. Widner DB, Park SH, Eber MR, Shiozawa Y. Interactions between disseminated tumor cells and bone marrow stromal cells regulate tumor dormancy. Curr Osteoporos Rep. 2018:16(5):596-602.

115. Yu-Lee L-Y, Yu G, Lee Y-C, Lin S-C, Pan J, Pan T, et al. Osteoblast-secreted factors mediate dormancy of metastatic prostate cancer in the bone via activation of the TGF $\beta$ RIII-p38MAPK-pS249/T252RB pathway. Cancer Res. 2018;78(11):2911-24

116. Gao H, Chakraborty G, Lee-Lim AP, Mo Q, Decker M, Vonica A, et al. The BMP inhibitor Coco reactivates breast cancer cells at lung metastatic sites. Cell. 2012;150(4):764-79.

117. Bartosh TJ, Ullah M, Zeitouni S, Beaver J, Prockop DJ. Cancer cells enter dormancy after cannibalizing mesenchymal stem/stromal cells (MSCs). Proc Natl Acad Sci. 2016;113(42):E6447-56

118. Chong MSK, Lim J, Goh J, Sia MW, Chan JKY, Teoh SH. Cocultures of mesenchymal stem cells and endothelial cells as organotypic models of prostate cancer metastasis. Mol Pharm. 2014;11(7):2126-33.

119. Wheeler SE, Clark AM, Taylor DP, Young CL, Pillai VC, Stolz DB, et al. Spontaneous dormancy of metastatic breast cancer cells in an all human liver microphysiologic system. Br J Cancer. 2014;111(12):2342-50.
120. Pavan Grandhi TS, Potta T, Nitiyanandan R, Deshpande I, Rege K. Chemomechanically engineered 3D organotypic platforms of bladder cancer dormancy and reactivation. Biomaterials. 2017;142:171-85.

121. Bliss SA, Sinha G, Sandiford OA, Williams LM, Engelberth DJ, Guiro K, et al. Mesenchymal stem cell-derived exosomes stimulate cycling quiescence and early breast cancer dormancy in bone marrow. Cancer Res. 2016;76(19): 5832-44.

122. Ono M, Kosaka N, Tominaga N, Yoshioka Y, Takeshita F, Takahashi RU, et al. Exosomes from bone marrow mesenchymal stem cells contain a microRNA that promotes dormancy in metastatic breast cancer cells. Sci Signal. 2014; 7(332):ra63.

123. Clapé C, Fritz V, Henriquet C, Apparailly F, Fernandez PL, Iborra F, et al. miR143 interferes with ERK5 signaling, and abrogates prostate cancer progression in mice. Creighton C, editor. PLOS ONE. 2009;4(10):e7542.

124. Cimmino A, Calin GA, Fabbri M, lorio MV, Ferracin M, Shimizu M, et al. miR15 and miR-16 induce apoptosis by targeting BCL2. Proc Natl Acad Sci U S A. 2005;102(39):13944-9.

125. Gao S, Xing C, Chen C, Lin S, Dong P, Yu F. miR-15a and miR-16-1 inhibit the proliferation of leukemic cells by down-regulating WT1 protein level. J Exp Clin Cancer Res. 2011;30:110.

126. Kosaka N, Yoshioka Y, Fujita Y, Ochiya T. Versatile roles of extracellular vesicles in cancer. J Clin Invest. 2016;126(4):1163-72.

127. Plebanek MP, Angeloni NL, Vinokour E, Li J, Henkin A, Martinez-Marin D, et al. Pre-metastatic cancer exosomes induce immune surveillance by patrolling monocytes at the metastatic niche. Nat Comm. 2017;8(1):1319 https://doi.org/10.1038/s41467-017-01433-3.

128. Fang JY, Tan S-J, Yang Z, Tayag C, Han B. Tumor bioengineering using a transglutaminase crosslinked hydrogel. PLoS ONE. 2014;9(8):e105616.

129. Lee HR, Leslie F. Azarin SM, A facile in vitro platform to study cancer cell dormancy under hypoxic microenvironments using $\mathrm{CoCl}_{2}$. J Biol Eng. 2018: 12(1). https://doi.org/10.1186/s13036-018-0106-7.

130. Sertil AR. Hypoxia and tumor dormancy: Can the two tango? In: Hayat MA, editor. Tumor Dormancy, Quiescence, and Senescence, vol. 3. Dordrecht: Springer Netherlands; 2014. p. 13-24. isbn:978-94-017-9325-4.

131. Qiu G-Z, Jin M-Z, Dai J-X, Sun W, Feng J-H, Jin W-L. Reprogramming of the tumor in the hypoxic niche: The emerging concept and associated therapeutic strategies. Trends Pharmacol Sci. 2017;38(8):669-86.

132. Endo $\mathrm{H}$, Okuyama $\mathrm{H}$, Ohue $\mathrm{M}$, Inoue M. Dormancy of cancer cells with suppression of AKT activity contributes to survival in chronic hypoxia. PLoS ONE. 2014;9(6):e98858.

133. Carcereri de Prati A, Butturini E, Rigo A, Oppici E, Rossin M, Boriero D, et al. Metastatic breast cancer cells enter into dormant state and express cancer stem cells phenotype under chronic hypoxia. J Cell Biochem. 2017;118(10): 3237-48.

134. Fluegen G, Avivar-Valderas A, Wang Y, Padgen MR, Williams JK, Nobre $A R$, et al. Phenotypic heterogeneity of disseminated tumour cells is preset by primary tumour hypoxic microenvironments. Nat Cell Biol. 2017;19(2):120-32.

135. Tivari $\mathrm{S}$, Korah $\mathrm{R}$, Lindy M, Wieder R. An in vitro dormancy model of estrogen-sensitive breast cancer in the bone marrow: A tool for molecular mechanism studies and hypothesis generation. J Vis Exp. 2015;100:e52672 https://doi.org/10.3791/52672.

136. Korah RM, Sysounthone V, Golowa Y, Wieder R. Basic fibroblast growth factor confers a less malignant phenotype in MDA-MB-231 human breast cancer cells. Cancer Res. 2000;60(3):733-40.

137. Barrios J, Wieder R. Dual FGF-2 and intergrin a $5 \beta 1$ signaling mediate GRAFinduced RhoA inactivation in a model of breast cancer dormancy. Cancer Microenviron. 2009;2(1):33-47.

138. Korah R, Boots M, Wieder R. Integrin alpha5beta1 promotes survival of growth-arrested breast cancer cells: an in vitro paradigm for breast cancer dormancy in bone marrow. Cancer Res. 2004;64(13):4514-22.

139. Sosnoski DM, Norgard RJ, Grove CD, Foster SJ, Mastro AM. Dormancy and growth of metastatic breast cancer cells in a bone-like microenvironment Clin Exp Metastasis. 2015;32(4):335-44.

140. Tivari S, Lu H, Dasgupta T, De Lorenzo MS, Wieder R. Reawakening of dormant estrogen-dependent human breast cancer cells by bone marrow stroma secretory senescence. Cell Commun Signal. 2018;16(1):48. https://doi. org/10.1186/s12964-018-0259-5.

141. Sosa MS, Parikh F, Maia AG, Estrada Y, Bosch A, Bragado P, et al. NR2F1 controls tumour cell dormancy via SOX9- and RARß-driven quiescence programmes. Nat Comm. 2015;6(1):6170. DOI: 10.1038/ncomms7170 
142. Cabezas-Wallscheid N, Buettner F, Sommerkamp P, Klimmeck D, Ladel L, Thalheimer FB, et al. Vitamin A-retinoic acid signaling regulates hematopoietic stem cell dormancy. Cell. 2017;169(5):807-823.e19.

143. Ghiaur G, Yegnasubramanian S, Perkins B, Gucwa JL, Gerber JM, Jones RJ. Regulation of human hematopoietic stem cell self-renewal by the microenvironment's control of retinoic acid signaling. Proc Natl Acad Sci U S A. 2013;110(40):16121-6.

144. O'Reilly MS, Holmgren L, Chen C, Folkman J. Angiostatin induces and sustains dormancy of human primary tumors in mice. Nat Med. 1996;2(6):689-92.

145. Indraccolo S. Insights into the regulation of tumor dormancy by angiogenesis in experimental tumors. Adv Exp Med Biol. 2013;734:37-52.

146. de Anta JM, Mayo C, Solé F, Salido M, Espinet B, Corzo C, et al. Methotrexate resistance in vitro is achieved by a dynamic selection process of tumor cell variants emerging during treatment. Int J Cancer. 2006;119(7):1607-15.

147. Wu F-H, Mu L, Li X-L, Hu Y-B, Liu H, Han L-T, et al. Characterization and functional analysis of a slow-cycling subpopulation in colorectal cancer enriched by cell cycle inducer combined chemotherapy. Oncotarget. 2017; 8(45):78466-79.

148. Li S, Kennedy M, Payne S, Kennedy K, Seewaldt VL, Pizzo SV, et al. Model of tumor dormancy/recurrence after short-term chemotherapy. PLOS ONE. 2014;9(5):e98021.

149. Smith TM, Butler SE, Wang X-YS, Manjili MH. Low-dose chemotherapy induces immunogenic tumor dormancy in mouse mammary carcinoma cells. J Immunol. 2017;198(1 Supplement):204.14.

150. Aqbi HF, Butler SE, Keim R, Idowu MO, Manjili MH. Chemotherapy-induced tumor dormancy and relapse. J Immunol. 2017;198(1 Supplement):204.7.

151. Tomoda R, Seto M, Hioki Y, Sonoda J, Matsumine A, Kusuzaki K, et al. Lowdose methotrexate inhibits lung metastasis and lengthens survival in rat osteosarcoma. Clin Exp Metastasis. 2005;22(7):559-64.

152. Zhou N, Wu X, Yang B, Yang X, Zhang D, Qing G. Stem cell characteristics of dormant cells and cisplatin-induced effects on the stemness of epithelial ovarian cancer cells. Mol Med Rep. 2014;10(5):2495-504.

153. Muthusamy P, Chary KV, Nalini GK. Metronomic chemotherapy: Seems prowess to battle against cancer in current scenario. J Clin Diagn Res. 2016; 10(11):FC09-13.

154. Natale G, Bocci G. Does metronomic chemotherapy induce tumor angiogenic dormancy? A review of available preclinical and clinical data. Cancer Lett. 2018;432:28-37.

155. Rabanal C, Ruiz R, Neciosup S, Gomez H. Metronomic chemotherapy for non-metastatic triple negative breast cancer: Selection is the key. World J Clin Oncol. 2017;8(6):437-46.

156. André N, Tsai K, Carré M, Pasquier E. Metronomic chemotherapy: Direct targeting of cancer cells after all? Trends Cancer. 2017;3(5):319-25.

157. Ramirez M, Rajaram S, Steininger RJ, Osipchuk D, Roth MA, Morinishi LS, et al. Diverse drug-resistance mechanisms can emerge from drug-tolerant cancer persister cells. Nat Commun. 2016;7:10690.

158. Weidenfeld K, Barkan D. EMT and stemness in tumor dormancy and outgrowth: Are they intertwined processes? Front Oncol. 2018;8:381. https:// doi.org/10.3389/fonc.2018.00381.

159. Weidenfeld K, Schif-Zuck S, Abu-Tayeh H, Kang K, Kessler O, Weissmann M, et al. Dormant tumor cells expressing LOXL2 acquire a stem-like phenotype mediating their transition to proliferative growth. Oncotarget. 2016;7(44): 71362-77.

160. Indraccolo S, Minuzzo S, Masiero M, Pusceddu I, Persano L, Moserle L, et al. Cross-talk between tumor and endothelial cells involving the Notch3-D\|l4 interaction marks escape from tumor dormancy. Cancer Res. 2009;69(4):1314-23.

161. Rossnagl S, Ghura H, Groth C, Altrock E, Jakob F, Schott S, et al. A subpopulation of stromal cells controls cancer cell homing to the bone marrow. Cancer Res. 2018;78(1):129-42.

162. Barkan D, El Touny LH, Michalowski AM, Smith JA, Chu I, Davis AS, et al. Metastatic growth from dormant cells induced by a Col---enriched fibrotic environment. Cancer Res. 2010;70(14):5706-16.

163. Barkan D, Green JE. An in vitro system to study tumor dormancy and the switch to metastatic growth. J Vis Exp. 2011;54:2914. https://doi.org/10.3791/2914.

164. Sansone P, Savini C, Kurelac I, Chang Q, Amato LB, Strillacci A, et al. Packaging and transfer of mitochondrial DNA via exosomes regulate escape from dormancy in hormonal therapy-resistant breast cancer. Proc Natl Acad Sci. 2017;114(43):E9066-75.

165. Costa-Silva B, Aiello NM, Ocean AJ, Singh S, Zhang H, Thakur BK, et al. Pancreatic cancer exosomes initiate pre-metastatic niche formation in the liver. Nat Cell Biol. 2015;17(6):816-26.
166. Syn N, Wang L, Sethi G, Thiery J-P, Goh B-C. Exosome-mediated metastasis: From epithelial-mesenchymal transition to escape from immunosurveillance. Trends Pharmacol Sci. 2016;37(7):606-17.

167. Steinbichler TB, Dudás J, Riechelmann H, Skvortsova I-I. The role of exosomes in cancer metastasis. Semin Cancer Biol. 2017;44:170-81.

168. Lobb RJ, Lima LG, Möller A. Exosomes: Key mediators of metastasis and premetastatic niche formation. Semin Cell Dev Biol. 2017;67:3-10.

169. Becker A, Thakur BK, Weiss JM, Kim HS, Peinado H, Lyden D. Extracellular vesicles in cancer: Cell-to-cell mediators of metastasis. Cancer Cell. 2016; 30(6):836-48.

170. Hoshino A, Costa-Silva B, Shen T-L, Rodrigues G, Hashimoto A, Tesic Mark M, et al. Tumour exosome integrins determine organotropic metastasis. Nature. 2015:527(7578):329-35.

171. Rodenhizer D, Dean T, D'Arcangelo E, McGuigan AP. The current landscape of $3 \mathrm{D}$ in vitro tumor models: What cancer hallmarks are accessible for drug discovery? Adv Healthc Mater. 2018;7(8):1701174.

172. Imamura Y, Mukohara T, Shimono Y, Funakoshi Y, Chayahara N, Toyoda M, et al. Comparison of 2D- and 3D-culture models as drug-testing platforms in breast cancer. Oncol Rep. 2015;33(4):1837-43.

173. Luskin MR, Murakami MA, Manalis SR, Weinstock DM. Targeting minimal residual disease: a path to cure? Nat Rev Cancer. 2018;18(4):255-63.

174. Aguirre-Ghiso JA, Bragado P, Sosa MS. Targeting dormant cancer. Nat Med. 2013;19(3):276-7.

175. Sosa MS. Dormancy programs as emerging antimetastasis therapeutic alternatives. Mol Cell Oncol. 2016:3(1):e1029062.

176. Hurst RE, Hauser PJ, You Y, Bailey-Downs LC, Bastian A, Matthews SM, et al. Identification of novel drugs to target dormant micrometastases. BMC Cancer. 2015;15(1):404. https://doi.org/10.1186/s12885-015-1409-4

177. Wenzel C, Riefke B, Gründemann S, Krebs A, Christian S, Prinz F, et al. 3D high-content screening for the identification of compounds that target cells in dormant tumor spheroid regions. Exp Cell Res. 2014;323(1):131-43.

178. Senkowski W, Jarvius M, Rubin J, Lengqvist J, Gustafsson MG, Nygren P, et al. Large-Scale gene expression profiling platform for identification of context-dependent drug responses in multicellular tumor spheroids. Cell Chem Biol. 2016;23(11):1428-38.

179. Cavnar SP, Rickelmann AD, Meguiar KF, Xiao A, Dosch J, Leung BM, et al. Modeling selective elimination of quiescent cancer cells from bone marrow. Neoplasia. 2015;17(8):625-33.

180. Kenny HA, Lal-Nag M, White EA, Shen M, Chiang C-Y, Mitra AK, et al. Quantitative high throughput screening using a primary human threedimensional organotypic culture predicts in vivo efficacy. Nat Comm. 2015; 6(1):6220. https://doi.org/10.1038/ncomms7220.

181. Najmi S, Korah R, Chandra R, Abdellatif M, Wieder R. Flavopiridol blocks integrin-mediated survival in dormant breast cancer cells. Clin Cancer Res. 2005;11(5):2038-46.

182. Ordóñez-Morán P, Huelsken J. Complex metastatic niches: already a target for therapy? Curr Opin Cell Biol. 2014;31:29-38.

183. Aguirre-Ghiso JA, Estrada Y, Liu D, Ossowski L. ERK(MAPK) activity as a determinant of tumor growth and dormancy; regulation by p38(SAPK). Cancer Res. 2003;63(7):1684-95

184. Sosa MS, Avivar-Valderas A, Bragado P, Wen H-C, Aguirre-Ghiso JA. ERK1/2 and $\mathrm{p} 38 \mathrm{a} / \mathrm{\beta}$ signaling in tumor cell quiescence: Opportunities to control dormant residual disease. Clin Cancer Res. 2011;17(18):5850-7.

185. Aguirre Ghiso JA, Kovalski K, Ossowski L. Tumor dormancy induced by downregulation of urokinase receptor in human carcinoma involves integrin and MAPK signaling. J Cell Biol. 1999;147(1):89-104.

186. Zhao W, Prijic S, Urban BC, Tisza MJ, Zuo Y, Li L, et al. Candidate Antimetastasis Drugs Suppress the Metastatic Capacity of Breast Cancer Cells by Reducing Membrane Fluidity. Cancer Res. 2016;76(7):2037-49.

187. Li Y, Rogoff HA, Keates S, Gao Y, Murikipudi S, Mikule K, et al. Suppression of cancer relapse and metastasis by inhibiting cancer stemness. Proc Natl Acad Sci. 2015;112(6):1839-44.

188. Ridker PM, MacFadyen JG, Thuren T, Everett BM, Libby P, Glynn RJ, et al. Effect of interleukin-1 $\beta$ inhibition with canakinumab on incident lung cancer in patients with atherosclerosis: exploratory results from a randomised, double-blind, placebo-controlled trial. Lancet Lond Engl. 2017; 390(10105):1833-42.

189. Yakes FM, Chen J, Tan J, Yamaguchi K, Shi Y, Yu P, et al. Cabozantinib (XL184), a novel MET and VEGFR2 inhibitor, simultaneously suppresses metastasis, angiogenesis, and tumor growth. Mol Cancer Ther. 2011;10(12): 2298-308. 
190. Frankowski KJ, Wang C, Patnaik S, Schoenen FJ, Southall N, Li D, et al. Metarrestin, a perinucleolar compartment inhibitor, effectively suppresses metastasis. Sci Transl Med. 2018;10(441):eaap8307.

191. Chen X, Li C, He T, Mao J, Li C, Lyu J, et al. Metformin inhibits prostate cancer cell proliferation, migration, and tumor growth through upregulation of PEDF expression. Cancer Biol Ther. 2016;17(5):507-14.

192. Cerezo M, Tichet M, Abbe P, Ohanna M, Lehraiki A, Rouaud F, et al. Metformin blocks melanoma invasion and metastasis development in AMPK/p53-dependent manner. Mol Cancer Ther. 2013;12(8):1605-15.

193. Bohl CR, Harihar S, Denning WL, Sharma R, Welch DR. Metastasis suppressors in breast cancers: mechanistic insights and clinical potential. J Mol Med Berl Ger. 2014;92(1):13-30

194. Goddard ET, Bozic I, Riddell SR, Ghajar CM. Dormant tumour cells, their niches and the influence of immunity. Nat Cell Biol. 2018;20(11):1240-9.

195. Carpenter RA, Kwak J-G, Peyton SR, Lee J. Implantable pre-metastatic niches for the study of the microenvironmental regulation of disseminated human tumour cells. Nat Biomed Eng. 2018. https://doi.org/10.1038/s41551-0180307-X.

196. Barkan D, Kleinman H, Simmons JL, Asmussen H, Kamaraju AK, Hoenorhoff MJ, et al. Inhibition of Metastatic Outgrowth from Single Dormant Tumor Cells by Targeting the Cytoskeleton. Cancer Res. 2008;68(15):6241-50.

Ready to submit your research? Choose BMC and benefit from:

- fast, convenient online submission

- thorough peer review by experienced researchers in your field

- rapid publication on acceptance

- support for research data, including large and complex data types

- gold Open Access which fosters wider collaboration and increased citations

- maximum visibility for your research: over $100 \mathrm{M}$ website views per year

At $B M C$, research is always in progress.

Learn more biomedcentral.com/submissions 